\title{
The evolution and storage of primitive melts in the Eastern Volcanic Zone of Iceland: the 10 ka Grímsvötn tephra series (i.e. the Saksunarvatn ash)
}

\author{
David A. Neave ${ }^{1,4} \cdot$ John Maclennan ${ }^{1} \cdot$ Thorvaldur Thordarson $^{2} \cdot$ \\ Margaret E. Hartley ${ }^{1,3}$
}

Received: 20 March 2015 / Accepted: 11 July 2015 / Published online: 7 August 2015

(C) The Author(s) 2015. This article is published with open access at Springerlink.com

\begin{abstract}
Major, trace and volatile elements were measured in a suite of primitive macrocrysts and melt inclusions from the thickest layer of the 10 ka Grímsvötn tephra series (i.e. Saksunarvatn ash) at Lake Hvítárvatn in central Iceland. In the absence of primitive tholeiitic eruptions $(\mathrm{MgO}>7 \mathrm{wt} \%)$ within the Eastern Volcanic Zone (EVZ) of Iceland, these crystal and inclusion compositions provide an important insight into magmatic processes in this volcanically productive region. Matrix glass compositions show strong similarities with glass compositions from the AD 1783-1784 Laki eruption, confirming the affinity of the tephra series with the Grímsvötn volcanic system. Macrocrysts can be divided into a primitive assemblage of zoned macrocryst cores $\left(\mathrm{An}_{78}-\mathrm{An}_{92}, \mathrm{Mg} \#_{\mathrm{cpx}}=82-87\right.$, $\left.\mathrm{Fo}_{79.5}-\mathrm{Fo}_{87}\right)$ and an evolved assemblage consisting of unzoned macrocrysts and the rims of zoned macrocrysts $\left(\mathrm{An}_{60}-\mathrm{An}_{68}, \mathrm{Mg} \#_{\mathrm{cpx}}=71-78, \mathrm{Fo}_{70}-\mathrm{Fo}_{76}\right)$. Although the
\end{abstract}

Communicated by Othmar Müntener.

Electronic supplementary material The online version of this article (doi:10.1007/s00410-015-1170-3) contains supplementary material, which is available to authorized users.

David A. Neave

d.neave@mineralogie.uni-hannover.de

1 Department of Earth Sciences, University of Cambridge, Downing Street, Cambridge CB2 3EQ, UK

2 Faculty of Earth Sciences, University of Iceland, Askja, Sturlugata 7, 101 Reykjavík, Iceland

3 School of Earth, Atmospheric and Environmental Sciences, University of Manchester, Oxford Road, Manchester M13 9PL, UK

4 Present Address: Institut für Mineralogie, Leibnitz Universität Hannover, Callinstr. 3, 30167 Hannover, Germany evolved assemblage is close to being in equilibrium with the matrix glass, trace element disequilibrium between primitive and evolved assemblages indicates that they were derived from different distributions of mantle melt compositions. Juxtaposition of disequilibrium assemblages probably occurred during disaggregation of incompatible trace element-depleted mushes (mean $\mathrm{La} / \mathrm{Yb}_{\text {melt }}=2.1$ ) into aphyric and incompatible trace element-enriched liquids $\left(\mathrm{La} / \mathrm{Yb}_{\text {melt }}=3.6\right)$ shortly before the growth of the evolved macrocryst assemblage. Post-entrapment modification of plagioclase-hosted melt inclusions has been minimal and high-Mg\# inclusions record differentiation and mixing of compositionally variable mantle melts that are amongst the most primitive liquids known from the EVZ. Coupled highfield strength element (HFSE) depletion and incompatible trace element enrichment in a subset of primitive plagioclase-hosted melt inclusions can be accounted for by inclusion formation following plagioclase dissolution driven by interaction with plagioclase-undersaturated melts. Thermobarometric calculations indicate that final crystal-melt equilibration within the evolved assemblage occurred at $\sim 1140{ }^{\circ} \mathrm{C}$ and $0.0-1.5$ kbar. Considering the large volume of the erupted tephra and textural evidence for rapid crystallisation of the evolved assemblage, $0.0-1.5 \mathrm{kbar}$ is considered unlikely to represent a pressure of long-term magma accumulation and storage. Multiple thermometers indicate that the primitive assemblage crystallised at high temperatures of $1240-1300{ }^{\circ} \mathrm{C}$. Different barometers, however, return markedly different crystallisation depth estimates. Raw clinopyroxene-melt pressures of 5.5-7.5 kbar conflict with apparent melt inclusion entrapment pressures of $1.4 \mathrm{kbar}$. After applying a correction derived from published experimental data, clinopyroxene-melt equilibria return mid-crustal pressures of $4 \pm 1.5 \mathrm{kbar}$, which are consistent with pressures estimated from the major element 
content of primitive melt inclusions. Long-term storage of primitive magmas in the mid-crust implies that low $\mathrm{CO}_{2}$ concentrations measured in primitive plagioclase-hosted inclusions (262-800 ppm) result from post-entrapment $\mathrm{CO}_{2}$ loss during transport through the shallow crust. In order to reconstruct basaltic plumbing system geometries from petrological data with greater confidence, mineral-melt equilibrium models require refinement at pressures of magma storage in Iceland. Further basalt phase equilibria experiments are thus needed within the crucial 1-7 kbar range.

Keywords Basalt $\cdot$ Saksunarvatn $\cdot$ Iceland $\cdot$ Plagioclasehosted melt inclusions $\cdot$ Thermobarometry

\section{Introduction}

\section{Primitive melts in the Eastern Volcanic Zone of Iceland}

Unmodified mantle melts rarely erupt at the Earth's surface. Numerous processes including crystallisation, mixing, assimilation and volatile exsolution affect primary melts as they ascend through the crust, overprinting geochemical records of mantle melting and source composition (Dungan and Rhodes 1978; Sinton and Detrick 1992; Langmuir et al. 1992; Rubin et al. 2009). Given that they host numerous primitive basalts and picrites, it is unsurprising that the Northern Volcanic Zone (NVZ) and Reykjanes Peninsula of Iceland have been the foci of intense geochemical study for some decades (Jakobsson et al. 1978; Elliott et al. 1991; Gurenko and Chaussidon 1995; Slater et al. 2001; Stracke et al. 2003; Thirlwall et al. 2004). Despite being the most volcanically active region of the country, no eruptions of primitive tholeiite $(\mathrm{MgO}>7 \mathrm{wt} \%)$ have been reported from within the Eastern Volcanic Zone (EVZ) of Iceland (Jakobsson 1979; Thordarson and Höskuldsson 2008). The evolution and storage of primitive melts in the EVZ must therefore be investigated using indirect methods such as studying primitive crystals and the melt inclusions they contain.

Studies of Icelandic melt inclusions have contributed to the understanding of numerous geological processes including mantle melting, magma mixing and volatile exsolution (e.g. Gurenko and Chaussidon 1995; Thordarson et al. 1996; Gurenko and Sobolev 2006; Maclennan 2008a, 2008b; Hartley et al. 2014). Most of these studies used olivine-hosted inclusions, the major element contents of which are susceptible to post-entrapment modification that obscures primitive melt compositions (Gaetani and Watson 2000; Danyushevsky et al. 2002). Here, we present data from a suite of predominantly plagioclase-hosted melt inclusions in which post-entrapment modification of major and trace elements has been minimal and primitive melt evolution processes can be discerned. Significant preeruptive modification of melt inclusion volatile contents has nevertheless taken place.

\section{Estimating magma storage depths}

In order to correlate geophysical records of volcanic unrest with petrological records of pre-eruptive processes (e.g. Saunders et al. 2012; Kilgour et al. 2014), it is important that magma storage depths can be estimated robustly from the erupted products of volcanoes. From amongst other methods, the depth of magmatic processes can be obtained from melt inclusion entrapment pressures (e.g. Dixon et al. 1995; Moore 2008), or from barometric calculations that exploit the sensitivity of mineral compositions to pressure (e.g. Nimis 1995; Putirka et al. 1996). However, petrologically determined magma storage depths are subject to various uncertainties and pitfalls that can result in different methods returning incoherent depth estimates (Métrich and Wallace 2008; Putirka 2008). The presence of clinopyroxene macrocrysts in equilibrium with glassy melt inclusions in the $10 \mathrm{ka}$ Grímsvötn tephra series offers an excellent opportunity for comparing different barometric techniques within the products of a single eruption. We find that discrepancies between different barometric techniques are greater than quoted model uncertainties as a result of incomplete calibration of clinopyroxene-melt equilibrium at the conditions relevant to magma storage in Iceland and pre-eruptive $\mathrm{CO}_{2}$ leakage of from melt inclusions.

\section{The 10 ka Grímsvötn tephra series (i.e. the Saksunarvatn ash)}

The tephra horizon commonly referred to as the Saksunarvatn ash occurs in a broad swathe across the North Atlantic from the Greenland ice cap to northern Germany (Mangerud et al. 1986; Grönvold et al. 1995; Merkt et al. 1993; Haflidason et al. 2000; Bramham-Law et al. 2013; Fig. 1). As such, it forms an important regional tephrochronological marker in Holocene sediment and ice formations (e.g. Rasmussen et al. 2006; Thornalley et al. 2011). Although the type locality, Lake Saksunarvatn, is in the Faroe Islands (Waagstein and Jóhansen 1968; Jóhansen 1975, 1985), the composition of the tephra shows that it originated in Iceland, more precisely from the Grímsvötn volcanic system in south central Iceland (e.g. Grönvold et al. 1995; Jennings et al. 2014). Specifically, the Saksunarvatn ash bears a striking compositional resemblance to the $\sim 15.1 \mathrm{~km}^{3}$ AD 1783-1784 Laki eruption products, which are slightly less evolved than typical magmas erupted at the Grímsvötn central volcano (Thordarson 2014). 


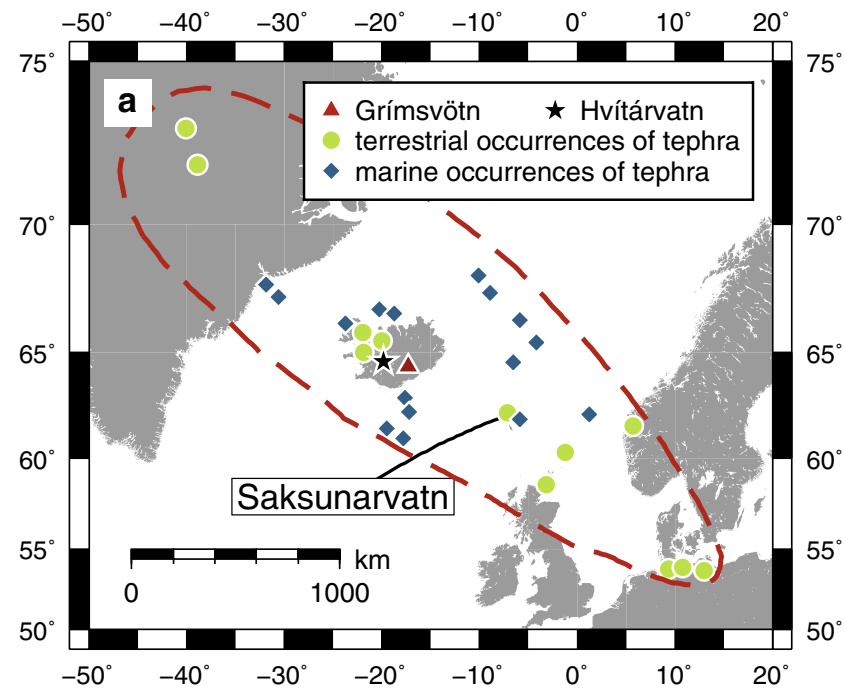

Fig. 1 a Map showing the extent (red dashed line) of the $10 \mathrm{ka}$ Grímsvötn tephra series (i.e. Saksunarvatn ash) according to Bramham-Law et al. (2013). Terrestrial deposits are shown as green circles, and marine deposits are shown as blue diamonds. Samples were collected from Lake Hvítárvatn in central Iceland, which is marked

The Saksunarvatn ash tephra layer has a primary thickness of 5-10 $\mathrm{mm}$ in the Faroe Islands (Mangerud et al. 1986), which implies that the tephra layer is at least volumetrically equivalent to the largest explosive basalt eruptions in Iceland during historical time, namely the $\sim 3.3 \mathrm{~km}^{3}$ AD 870 Vatnaöldur and $\sim 6.7 \mathrm{~km}^{3}$ AD 1477 Veiðivötn basaltic phreatoplinian eruptions (Larsen, 1984, 2005). Furthermore, recent studies have shown that the Saksunarvatn ash horizon is composed of tephra fall from at least six eruptions that took place in the Grímsvötn volcanic system over the period $10.5 \mathrm{ka}$ to $9.9 \mathrm{ka}$, each ranging in volume from $>1-30 \mathrm{~km}^{3}$ (Jóhannsdóttir et al. 2005; Jennings et al. 2014; Thordarson 2014). Ash from five of these events was dispersed westwards from the source vent, whilst ash from at least one event (i.e. the Saksunarvatn ash proper) was dispersed towards the east. Whilst all of these tephra layers have identical major element compositions (Table 1), a more thorough petrological characterisation has yet to be undertaken. Hereafter, these tephra layers are referred to as the $10 \mathrm{ka}$ Grímsvötn tephra series, in order to distinguish the series from the Saksunarvatn ash proper that is observed in the Faroe Islands (Jennings et al. 2014; Thordarson 2014).

\section{Sample collection and preparation}

Glass and crystal fragments $150-800 \mu \mathrm{m}$ in size were selected from the thickest layer of the 10 ka Grímsvötn tephra series (Saks-eq II HVT) observed in the

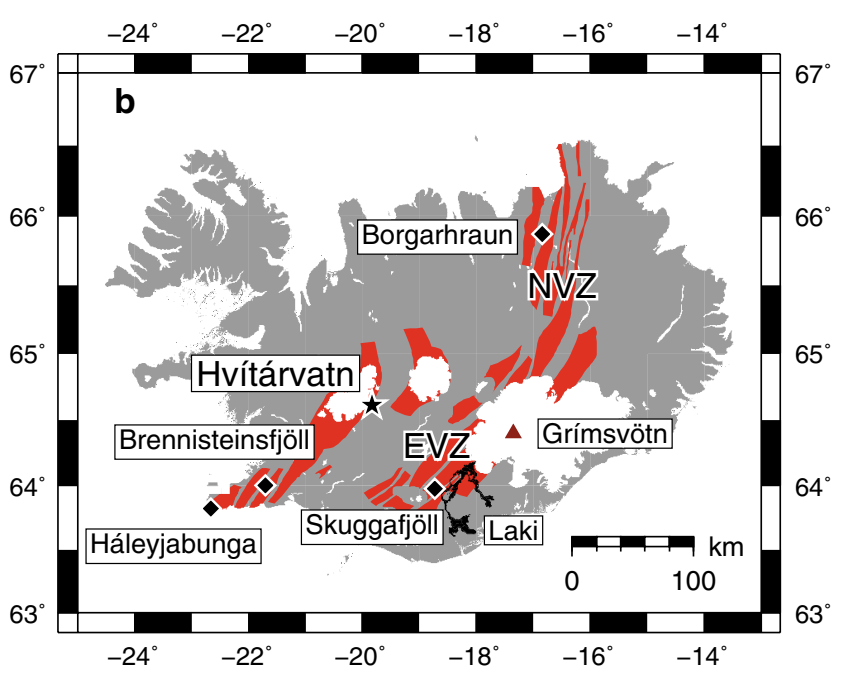

by a black star. The Grímsvötn central volcano is marked by a red triangle. b Map of Iceland showing the location of various localities discussed in the text including the Eastern Volcanic Zone (EVZ), Northern Volcanic Zone (NVZ) and Reykjanes Peninsula (REP). Volcanic systems are shaded in red

GLAD-HVT03-1A-7H core collected from Lake Hvítárvatn in 2003 (Fig. 1). Saks-eq II HVT is dated to approximately 10.35 ka (Jóhannsdóttir 2007; Rasmussen et al., 2006; Lohne et al. 2014) and is henceforth referred to as the Hvítárvatn tephra layer. Tephra consists mainly of highly vesicular, holohyaline tephra clasts, and contains conspicuous colourless plagioclase fragments. Fragments of dark green clinopyroxene and pale green olivine are also present. In order to avoid using genetic terms such as phenocryst, xenocryst and antecryst, all crystals larger than $150 \mu \mathrm{m}$ are referred to as macrocrysts hereafter (c.f. Thomson and Maclennan 2013).

After being washed in distilled water and then dried, macrocrysts were mounted in Buehler EpoThin ${ }^{\mathrm{TM}}$ resin and polished to expose melt inclusions for analysis. Not all melt inclusions were exposed after the first round of polishing. In order to maximise the number of melt inclusion analyses in different host crystals given the small volume of sample material available, crystals were re-polished after a first round of analyses in order to expose a second plane of melt inclusions deeper within the samples.

\section{Analytical methods}

Backscattered electron (BSE) images were produced using a JEOL JSM-820 scanning electron microscope (SEM) in the Department of Earth Sciences at the University of Cambridge, UK. Trace elements in melt inclusions, matrix glasses and clinopyroxene macrocrysts were measured by 


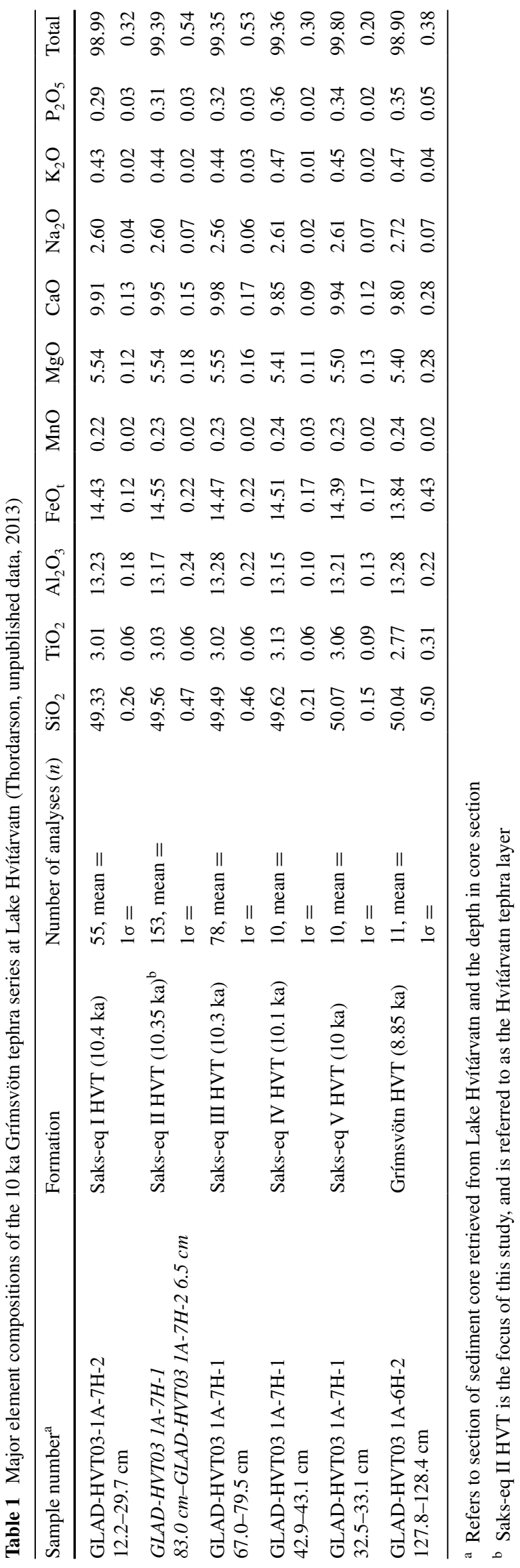


secondary ion mass spectrometry (SIMS). $\mathrm{CO}_{2}$ and $\mathrm{H}_{2} \mathrm{O}$ were also measured in glasses by SIMS. Major elements in all samples were measured by electron probe microanalysis (EPMA). Inclusion-hosted bubbles were investigated by Raman spectroscopy in order to determine whether they contained $\mathrm{CO}_{2}$.

\section{Secondary ion mass spectrometry (SIMS)}

SIMS analyses were performed at the NERC Ion Microprobe Facility at the University of Edinburgh using a Cameca ims-4f instrument. Analyses of $\mathrm{CO}_{2}$ in glasses were carried out first in order to avoid introducing surface contamination from carbon coating. Analyses were carried out with the instrument configured for a high mass resolving power in order to ensure separation of ${ }^{12} \mathrm{C}$ and ${ }^{24} \mathrm{Mg}^{2+}$ peaks. Measurements were taken using a primary $\mathrm{O}^{-}$ion beam with an accelerating voltage of $15 \mathrm{kV}$, a beam current of $6 \mathrm{nA}$, a secondary accelerating voltage of $4500 \mathrm{~V}$ minus a $50 \mathrm{~V}$ offset and a $25-\mu \mathrm{m}$ image field. The ion beam was rastered over an area of approximately $25 \mu^{2}$ for $120 \mathrm{~s}$ prior to analysis to remove surface contamination. The raster was then switched off, and a $10 \mu \mathrm{m}$ beam centred in the middle of the rastered area was used to make measurements. The following mass positions and isotopes were measured for 16 cycles, with counting times in seconds in parentheses: ${ }^{12} \mathrm{C}(5),{ }^{24} \mathrm{Mg}^{2+}(10),{ }^{28} \mathrm{Si}^{2+}(2)$ and ${ }^{30} \mathrm{Si}(2)$. Counts from the final eight cycles were used to calculate $\mathrm{CO}_{2}$ concentrations using a calibration curve constructed from basaltic glass standards from Shishkina et al. (2010) containing 0-2000 ppm $\mathrm{CO}_{2}$. Precision was estimated as $1 \sigma= \pm 5.9 \%$ using repeat analyses of both standards and samples.

Analyses of $\mathrm{H}_{2} \mathrm{O}$ and trace elements in glass were then undertaken using a primary $\mathrm{O}^{-}$ion beam with an accelerating voltage of $15 \mathrm{kV}$, a beam current of $6 \mathrm{nA}$, a secondary accelerating voltage of $4500 \mathrm{~V}$ minus a $75 \mathrm{~V}$ offset and a $25-\mu \mathrm{m}$ image field. Analyses were made with a spot size of $\sim 15 \mu \mathrm{m}$ centred in the pit formed during preceding $\mathrm{CO}_{2}$ analyses. The following isotopes were measured for eight cycles, with counting times in seconds in parentheses: atomic mass $0.7(3),{ }^{1} \mathrm{H}(5),{ }^{30} \mathrm{Si}(2),{ }^{39} \mathrm{~K}(3),{ }^{47} \mathrm{Ti}(3),{ }^{88} \mathrm{Sr}(3)$, ${ }^{89} \mathrm{Y}(3),{ }^{90} \mathrm{Zr}(3),{ }^{93} \mathrm{Nb}(3)$, atomic mass $130.5(3),{ }^{138} \mathrm{Ba}(3)$, ${ }^{139} \mathrm{La}(3),{ }^{140} \mathrm{Ce}(3),{ }^{141} \mathrm{Pr}(5),{ }^{143} \mathrm{Nd}(5),{ }^{149} \mathrm{Sm}(8),{ }^{151} \mathrm{Eu}(10)$, ${ }^{156} \mathrm{Gd}(5), \quad{ }^{159} \mathrm{~Tb}(10), \quad{ }^{161} \mathrm{Dy}(10),{ }^{165} \mathrm{Ho}(10), \quad{ }^{167} \operatorname{Er}(15)$, ${ }^{169} \mathrm{Tm}(20),{ }^{174} \mathrm{Yb}(20)$ and ${ }^{175} \mathrm{Lu}(20)$. Peak positions were verified before each analysis, and masses 0.7 and 130.5 were measured to determine backgrounds in each cycle, which were always sufficiently close to zero to be ignored.

$\mathrm{H}_{2} \mathrm{O}$ concentrations were calculated using a calibration curve constructed from basaltic glass standards from Shishkina et al. (2010) containing 0-2.96 wt $\% \mathrm{H}_{2} \mathrm{O}$. Precision was estimated as $1 \sigma= \pm 3.9 \%$ using repeat analyses of both standards and samples. Absolute trace element concentrations were calculated using JCION-6 software, where corrections were made for oxide interferences of light REEs on heavy REEs and $\mathrm{BaO}$ on Eu. NIST-610 was used as the primary calibration standard (Jochum et al. 2011), and matrix corrections were applied using the synthetic basalt standard GSD-1G (Jochum et al. 2005). Accuracy was monitored using international standards ML3B-G, GOR128-G, BCR2-G and KL2-G (Jochum et al. 2006) and was generally better than $\pm 5 \%$ for trace elements. Precision was estimated as better than $1 \sigma= \pm 5 \%$ for trace elements of high abundance (e.g. $\mathrm{Zr}$ and $\mathrm{Sr}$ ), and as better than $1 \sigma= \pm 10 \%$ for trace elements of low abundance (e.g. Yb and $\mathrm{Lu}$ ) using repeat analyses of samples.

Trace elements in clinopyroxenes were analysed using the same conditions as for trace element analyses of glasses. NIST-610 was used as the primary calibration standard (Jochum et al. 2011). NIST-610 has similar ion yield patterns and efficiencies to clinopyroxene, negating the requirement for matrix corrections (Winpenny and Maclennan 2011). The following isotopes were measured for eight cycles, with counting times in seconds in parentheses: ${ }^{40} \mathrm{Ca}(5),{ }^{44} \mathrm{Ca}(5),{ }^{45} \mathrm{Sc}(5),{ }^{47} \mathrm{Ti}(3),{ }^{88} \mathrm{Sr}(3),{ }^{89} \mathrm{Y}(3)$, ${ }^{90} \mathrm{Zr}(3),{ }^{93} \mathrm{Nb}(3)$, atomic mass $130.5(3),{ }^{138} \mathrm{Ba}(3),{ }^{139} \mathrm{La}(3)$, ${ }^{140} \mathrm{Ce}(3),{ }^{141} \mathrm{Pr}(5),{ }^{143} \mathrm{Nd}(5),{ }^{149} \mathrm{Sm}(8),{ }^{151} \mathrm{Eu}(10),{ }^{156} \mathrm{Gd}(5)$, ${ }^{159} \mathrm{~Tb}(10),{ }^{161} \mathrm{Dy}(10),{ }^{165} \mathrm{Ho}(10),{ }^{167} \operatorname{Er}(15),{ }^{169} \mathrm{Tm}(20)$, ${ }^{174} \mathrm{Yb}(20)$ and ${ }^{175} \mathrm{Lu}(20)$. Corrections were made for ${ }^{44} \mathrm{CaH}^{+}$interferences on ${ }^{45} \mathrm{Sc}$. Precision was estimated as better than $1 \sigma= \pm 5-15 \%$ depending on element abundance using repeat analyses of samples.

\section{Electron probe microanalysis (EPMA)}

EPMA was performed at the University of Cambridge using a Cameca SX100 instrument. Glass analyses were performed with an operating potential of $15 \mathrm{kV}$, a beam current of $10 \mathrm{nA}$ and a spot size of $5 \mu \mathrm{m}$ or $10 \mu \mathrm{m}$ depending on sample size. Olivine, clinopyroxene and $\mathrm{Mg}-\mathrm{Al}-$ chromite analyses were performed with an operating potential of $15 \mathrm{kV}$, a beam current of $20 \mathrm{nA}$ and a focussed beam. Plagioclase analyses were performed with a beam current of $10 \mathrm{nA}$ and a spot size of $5 \mu \mathrm{m}$ in order to minimise Na mobilisation. Counting times were as follows: $20 \mathrm{~s}$ for major elements in glass and crystals, except for Ti which was counted for $60 \mathrm{~s}$ and $\mathrm{Na}$ which was counted for $10 \mathrm{~s} ; 30 \mathrm{~s}$ for minor elements in crystals; and $60 \mathrm{~s}$ for P, Cr, $\mathrm{Mn}$ and $\mathrm{Ni}$ in glass. Calibration standards were as follows: jadeite for $\mathrm{Na}$, periclase for $\mathrm{Mg}$, Si glass for $\mathrm{Si}, \mathrm{K}$-feldspar for $\mathrm{K}$, rutile for $\mathrm{Ti}$, fayalite for $\mathrm{Fe}$, corundum for $\mathrm{Al}$, apatite for $\mathrm{P}$, and pure metals for $\mathrm{Cr}, \mathrm{Mn}$ and $\mathrm{Ni}$.

Repeat analyses of standards indicate that plagioclase anorthite content $(\mathrm{An}=100 \times$ atomic $\mathrm{Ca} /(\mathrm{Ca}+\mathrm{Na}+\mathrm{K}))$ was determined with a precision of $1 \sigma= \pm 0.5 \mathrm{~mol}$. \% 

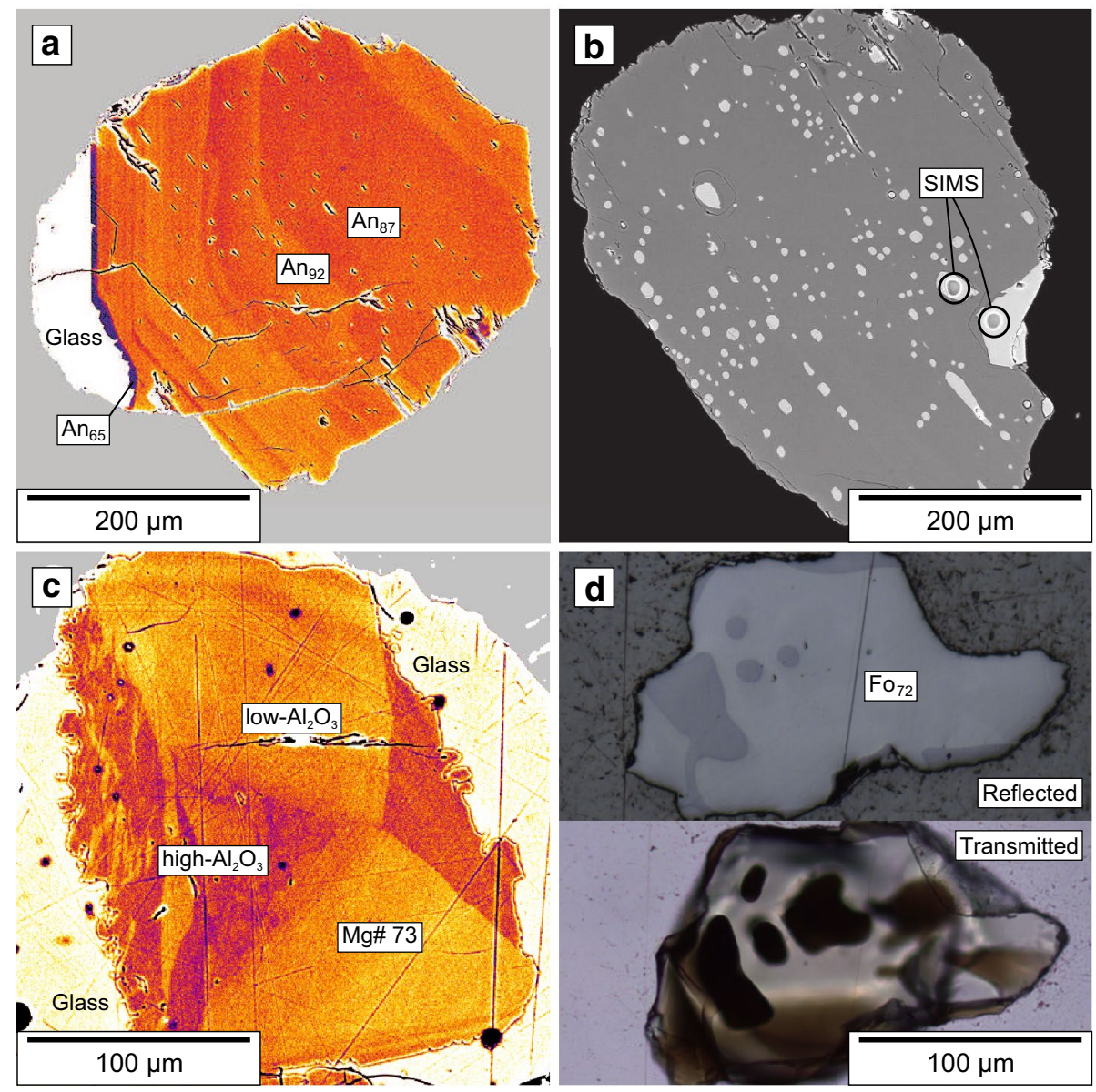

Fig. 2 a False-colour BSE image of a plagioclase macrocryst. Most of the crystal is composed of a high-anorthite core with low amplitude oscillatory zoning $\left(\mathrm{An}_{87}-\mathrm{An}_{92}\right)$ that is encased within a lowanorthite $\left(\mathrm{An}_{65}\right)$ rim. Note the sharp core/rim boundary and ragged skeletal nature of the rim. b BSE image showing the inclusion-rich nature of some plagioclase macrocrysts. Investigation of inclusionrich macrocrysts by optical microscopy reveals that inclusions are discrete - they are not joined by thin melt tubes. However, they may

and that olivine forsterite content $(\mathrm{Fo}=100 \times$ atomic $\left.\mathrm{Mg} /\left(\mathrm{Mg}+\mathrm{Fe}^{2+}\right)\right)$ was determined with a precision of $1 \sigma= \pm 0.23$ mol. \%. Clinopyroxene magnesium number $\left(\mathrm{Mg \#}=100 \times\right.$ atomic $\left.\mathrm{Mg} /\left(\mathrm{Mg}+\mathrm{Fe}^{2+}\right)\right)$ was determined with a precision similar to that obtained for olivine forsterite content. Precision was estimated as better than $1 \sigma= \pm 5 \%$ for major elements in glasses, but as poor as $1 \sigma= \pm 30-40 \%$ for minor elements in glasses $\left(\mathrm{MnO}, \mathrm{K}_{2} \mathrm{O}\right.$ and $\mathrm{P}_{2} \mathrm{O}_{5}$ ) using repeat analyses of samples.

\section{Raman spectroscopy}

A subset of inclusion-hosted bubbles was analysed by Raman spectroscopy using a Horiba LabRam ${ }^{\mathrm{TM}}$ instrument at the University of Cambridge, UK. The detection limit of $\mathrm{CO}_{2}$ in inclusion-hosted bubbles is better than have been joined at the time of formation. Circular features are pits formed during SIMS analyses. $\mathbf{c}$ False-colour BSE image of a low$\mathrm{Mg \#}$ clinopyroxene macrocryst highlighting sector zoning. Hourglass zoning in this clinopyroxene is primarily defined by the replacement of $\mathrm{Al}_{2} \mathrm{O}_{3}$ and $\mathrm{TiO}_{2}$ in the brighter, denser zones by $\mathrm{FeO}$ and $\mathrm{MgO}$. Note the skeletal nature of the macrocryst rim. d Reflected and transmitted light images of a low-forsterite olivine macrocryst that is ramified with melt inclusions and melt channels

$0.04 \mathrm{~g} / \mathrm{cm}^{3}$ based on analysis of $\mathrm{CO}_{2}$-bearing samples on the same instrument (Hartley et al. 2014).

\section{Results}

\section{Macrocryst compositions and textures}

Plagioclase, clinopyroxene and olivine macrocrysts are found throughout the Hvítárvatn tephra layer. Apparent macrocryst sizes are as follows: plagioclase, 200-800 $\mu \mathrm{m}$; clinopyroxene, 150-500 $\mu \mathrm{m}$; and olivine, 150-400 $\mu \mathrm{m}$. However, macrocrysts may have been significantly larger before syn-eruptive fragmentation. Occasional smaller crystals $(10-150 \mu \mathrm{m})$ are present within the matrix glass, but were not analysed. 


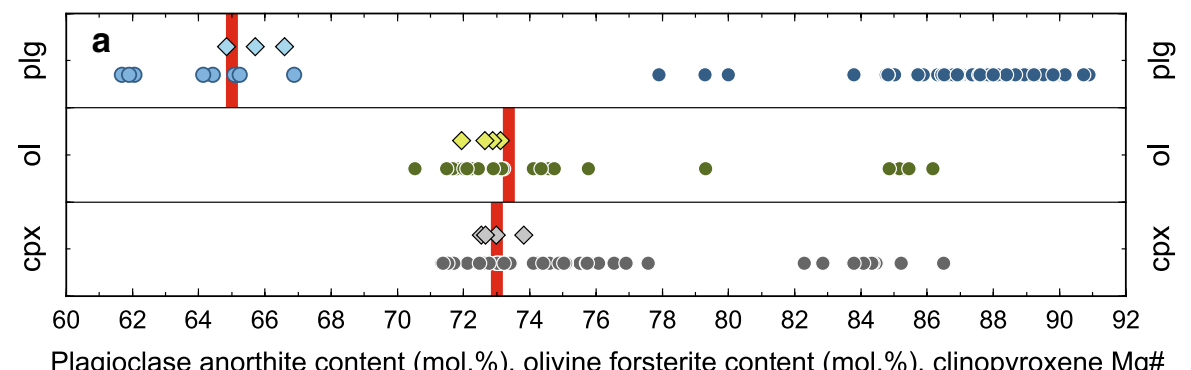

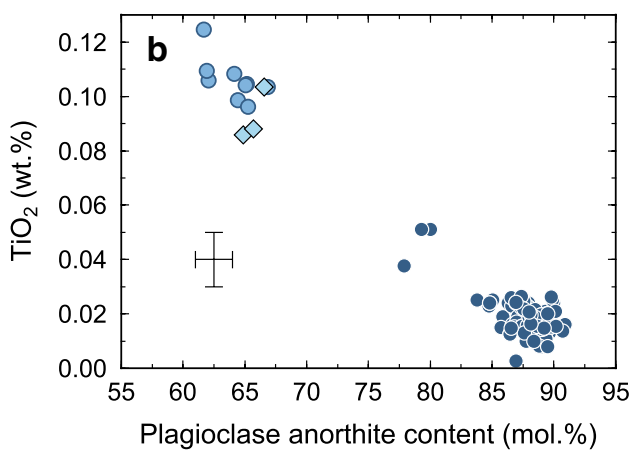

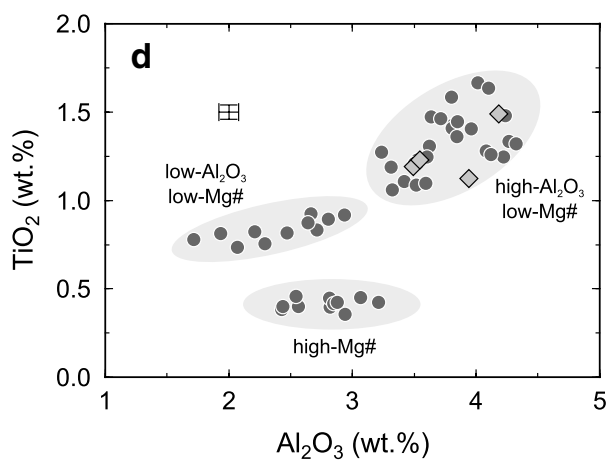

Fig. 3 Plots summarising the composition of macrocrysts from the Hvítárvatn tephra layer. $2 \sigma$ error bars are shown in b-d. a Major element composition of macrocryst cores and rims. Vertical red bars show plagioclase, olivine and clinopyroxene compositions in equilibrium with the matrix glass according to mineral-melt equilibrium models of Namur et al. (2011), Herzberg and O'Hara (2002) and Eq. 35 of Putirka (2008), respectively. b $\mathrm{TiO}_{2}$ content of plagioclase cores and rims plotted against anorthite content. c $\mathrm{TiO}_{2}$ content of

Plagioclase macrocrysts $(n=108)$ can be divided into two populations depending on whether they are compositionally zoned (Figs. 2a, 3a): zoned macrocrysts have primitive, high-anorthite cores $\left(\mathrm{An}_{83}-\mathrm{An}_{92}\right)$ encased within evolved, low-anorthite rims $\left(\sim \mathrm{An}_{65}\right)$, whereas unzoned macrocrysts have low-anorthite contents throughout $\left(A n_{60}-A_{68}\right)$. Two plagioclase macrocrysts have core compositions of $\mathrm{An}_{80}$. Trace elements also reflect core-rim zonation: anorthite content correlates negatively with $\mathrm{TiO}_{2}$

\section{$\frac{0}{2}$ $\overline{0}$ 응} matrix glass equilibrium $\checkmark$ olivine rims $\diamond$ clinopyroxene rims
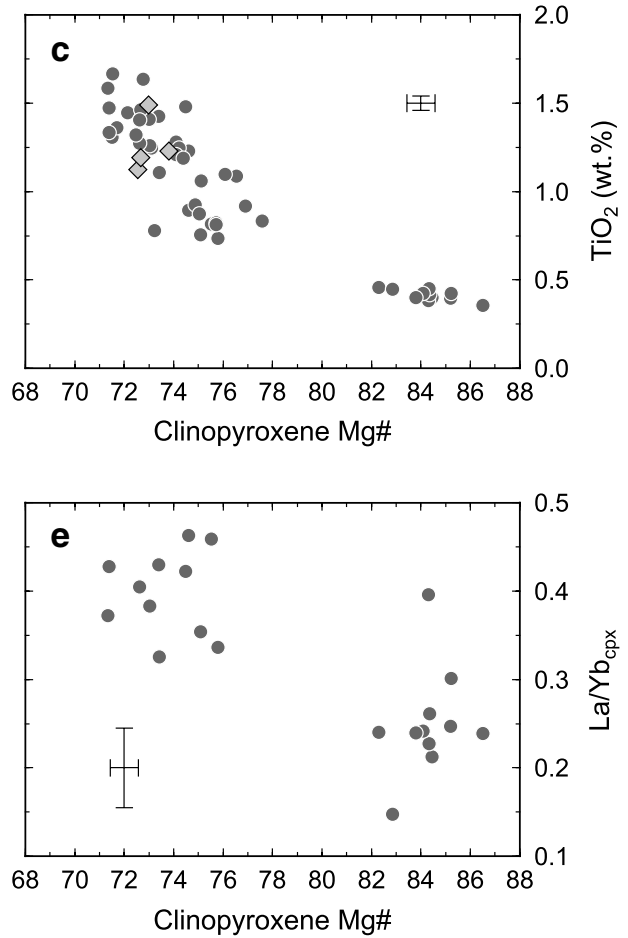

clinopyroxene cores and rims plotted against clinopyroxene $\mathrm{Mg \#}$. d $\mathrm{TiO}_{2}$ content of clinopyroxene macrocrysts plotted against $\mathrm{Al}_{2} \mathrm{O}_{3}$ to enable compositionally distinct sector zones to be discriminated (Fig. 2c). High- and low- $\mathrm{Al}_{2} \mathrm{O}_{3}$ low-Mg\# clinopyroxene zones are marked as well as high- $\mathrm{Mg} \#$ clinopyroxenes. e $\mathrm{La} / \mathrm{Yb}_{\mathrm{cpx}}$ in a subset of clinopyroxene cores analysed by SIMS plotted against clinopyroxene Mg\#

concentration (Fig. 3b). $\mathrm{Mg}-\mathrm{Al}$ chromites $(\mathrm{Cr} \#=41-51$, where $\mathrm{Cr} \#=100 \times$ atomic $\mathrm{Cr} /(\mathrm{Cr}+\mathrm{Al}))$ are found as rare inclusions within high-anorthite cores and are further characterised by low $\mathrm{TiO}_{2}$ contents $(<0.65 \mathrm{wt} \%)$.

BSE images reveal that anorthite content changes abruptly at the boundary between cores and rims and that low amplitude oscillatory zoning $\left(\mathrm{An}_{84}-\mathrm{An}_{92}\right)$ occurs within some high-anorthite cores (Fig. 2a). Whilst some cores contain no melt inclusions (Fig. 2a), others contain abundant 
small (5-40 $\mu \mathrm{m}$ in length) melt inclusions (Fig. 2b) that are often arranged into crystallographically controlled chains and concentric bands. Rare large inclusions up to $\sim 210 \mu \mathrm{m}$ in length are also present. Zoned plagioclase macrocryst rims are thin $(\sim 10 \mu \mathrm{m})$ and often skeletal in nature (Fig. 2a). Elongate, unzoned plagioclase macrocrysts are often texturally associated with low-Mg\# clinopyroxene macrocrysts, indicating that they represent the fragmented remains of ophitic glomerocrysts (c.f. AD 1783-84 Laki eruption; Guilbaud et al. 2007; Neave et al. 2013).

Clinopyroxene macrocrysts $(n=48)$ can also be divided into two populations based on their core compositions (Fig. 3a): a primitive population containing high-Mg\# cores $(\mathrm{Mg} \#=82-87)$ and an evolved population containing low$\mathrm{Mg} \#$ cores $(\mathrm{Mg} \#=71-78)$. Rims of high-Mg\# clinopyroxene macrocrysts are thin $(\sim 10 \mu \mathrm{m})$ and evolved $(\mathrm{Mg} \# \sim 73)$. Compositional bimodality is also reflected in clinopyroxene minor and trace element contents (Fig. 3c-e): high-Mg\# cores are characterised by low $\mathrm{TiO}_{2}(\sim 0.45 \mathrm{wt} \%)$ and $\mathrm{La} /$ $\mathrm{Yb}_{\text {cpx }}(0.25 \pm 0.06(1 \sigma))$, whereas low-Mg\# cores have higher $\mathrm{TiO}_{2}(>0.75 \mathrm{wt} \%)$ and $\mathrm{La} / \mathrm{Yb}_{\mathrm{cpx}}(0.40 \pm 0.04(1 \sigma))$.

Although high-Mg\# clinopyroxenes show no evidence of sector zoning - they form a single population on a plot of $\mathrm{Al}_{2} \mathrm{O}_{3}$ versus $\mathrm{TiO}_{2}$ (Fig. 3d)—low-Mg\# clinopyroxenes exhibit strong sector zoning (Fig. 2c). Low-Mg\# clinopyroxene analyses can be divided into a high- $\mathrm{Al}_{2} \mathrm{O}_{3}$ group $(>3 \mathrm{wt} \%$ ) that maintained crystal-melt equilibrium during growth, and a disequilibrium low- $\mathrm{Al}_{2} \mathrm{O}_{3}$ group. Sector zoning of this type results from the greater uptake of $\mathrm{Mg}$ and $\mathrm{Fe}^{2+}$ and concurrent dilution of $\mathrm{Ca}, \mathrm{Al}$ and $\mathrm{Ti}$ on $\{100\}$ faces with respect to on $\{010\}$ and $\{110\}$ faces during rapid crystal growth (Nakamura 1973). Therefore, only analyses from equilibrium low-Mg\# crystal zones (i.e. those with $\mathrm{Al}_{2} \mathrm{O}_{3}>3$ wt $\%)$ were used to evaluate clinopyroxene-melt trace element equilibrium and as the input for thermobarometric calculations. Skeletal textures around the rims of some clinopyroxenes provide further evidence of rapid growth.

Whilst most olivine macrocrysts $(n=32)$ have evolved core compositions $\left(\mathrm{Fo}_{70}-\mathrm{Fo}_{76}\right)$, a small number $(n=7)$ contain primitive cores $\left(\mathrm{Fo}_{84}-\mathrm{Fo}_{87}\right)$ and one has a core composition of $\mathrm{Fo}_{79.5}$ (Fig. 3a). Rims of primitive olivine macrocrysts are 10-20 $\mu \mathrm{m}$ thick and have low-forsterite contents $\left(\mathrm{Fo}_{72.5}\right)$ adjacent to the matrix glass. Whilst highforsterite olivines occur as rounded crystal fragments, lowforsterite olivines are often ramified with melt inclusions and exhibit skeletal textures (Fig. 2d).

\section{Matrix glass and melt inclusion compositions}

\section{Major elements}

Melt inclusion and matrix glass major element compositions are summarised in Fig. 4. Matrix glass compositions are homogeneous and similar to previously published values for the Saksunarvatn ash (Mangerud et al. 1986; Grönvold et al. 1995; Jóhannsdóttir et al. 2005; Jóhannsdóttir 2007; Bramham-Law et al. 2013).

Melt inclusions can be divided into two main populations based on the composition of their host crystals: primitive melt inclusions that are hosted within high-anorthite plagioclase and high-forsterite olivine and evolved melt inclusions that are hosted within low-anorthite plagioclase and low-forsterite olivine (Fig. 4). Primitive plagioclase-hosted melt inclusions $(n=113)$ are $\mathrm{MgO}$-rich $(\mathrm{MgO}=9.3-12.3$ $\mathrm{wt} \% ; \mathrm{Mg} \#=62-70$ ), whereas primitive olivine-hosted melt inclusions have lower $\mathrm{MgO}$ contents (5.8-6.1 wt\%), consistent with post-entrapment crystallisation and re-equilibration (Danyushevsky et al. 2002). Evolved plagioclase-hosted melt inclusions $(n=4)$ have low $\mathrm{MgO}$ contents $(\mathrm{MgO} \sim 5.4$ $\mathrm{wt} \% ; \mathrm{Mg \#} \sim 43)$ and are compositionally indistinguishable from the matrix glass. Additionally, five melt inclusions with $\mathrm{MgO}=8-8.5 \mathrm{wt} \%$ are hosted within $\sim \mathrm{An}_{80}$ plagioclase.

\section{Trace elements}

Matrix glass and melt inclusion trace element compositions are summarised on plots of selected element pairs (Fig. 5) and on a multi-element diagram normalised to depleted MORB mantle (DMM; Workman and Hart 2005) (Fig. 6). A cross-correlation matrix of elements in primitive plagioclase-hosted inclusions is provided in the Supplementary Material. Variability in trace element abundance between matrix glass samples is comparable with estimates of analytical precision $(1 \sigma= \pm 5-10 \%)$.

Primitive melt inclusions have lower concentrations of both highly and moderately incompatible trace elements than evolved melt inclusions and the matrix glass (Figs. 5, 6). Evolved melt inclusions are compositionally similar to the matrix glass in terms of both trace element abundances and trace element ratios (Fig. 5a): the mean matrix glass $\mathrm{La} / \mathrm{Yb}$ of $3.55 \pm 0.10(1 \sigma)$ is within analytical error of the mean evolved melt inclusion $\mathrm{La} / \mathrm{Yb}$ of $3.60 \pm 0.18(1 \sigma)$. In contrast, primitive melt inclusions are more diverse: primitive melt inclusion $\mathrm{La} / \mathrm{Yb}$ values span the range 1.08-3.41 (Fig. 5b). The matrix glass and evolved melt inclusions also have pronounced negative $\mathrm{Sr}$ anomalies $\left(\mathrm{Sr} / \mathrm{Sr}^{*}=0.49 \pm 0.02(1 \sigma)\right.$, where $\mathrm{Sr} / \mathrm{Sr}^{*}=\mathrm{Sr}_{\mathrm{n}} /$ $\left(\mathrm{Ce}_{\mathrm{n}} \times \mathrm{Nd}_{\mathrm{n}}\right)^{0.5}$ and $n=$ chondrite values from Arevalo and McDonough (2010)), whereas primitive melt inclusions have, on average, slightly positive anomalies $(\mathrm{Sr} /$ $\left.\mathrm{Sr}^{*}=1.13 \pm 0.15(1 \sigma)\right)$. There is no relationship between $\mathrm{La} / \mathrm{Yb}$ and $\mathrm{Sr} / \mathrm{Sr} *$ in primitive melt inclusions $(r=0.06)$.

All trace elements apart from $\mathrm{Yb}$ are significantly variable at the $99 \%$ confidence level within the primitive melt inclusion population, i.e. have signal-to-noise ratios $\left(\sigma_{t} / \sigma_{\mathrm{r}}\right.$, where $\sigma_{\mathrm{t}}$ is the true variability within a sample set and $\sigma_{\mathrm{r}}$ is 

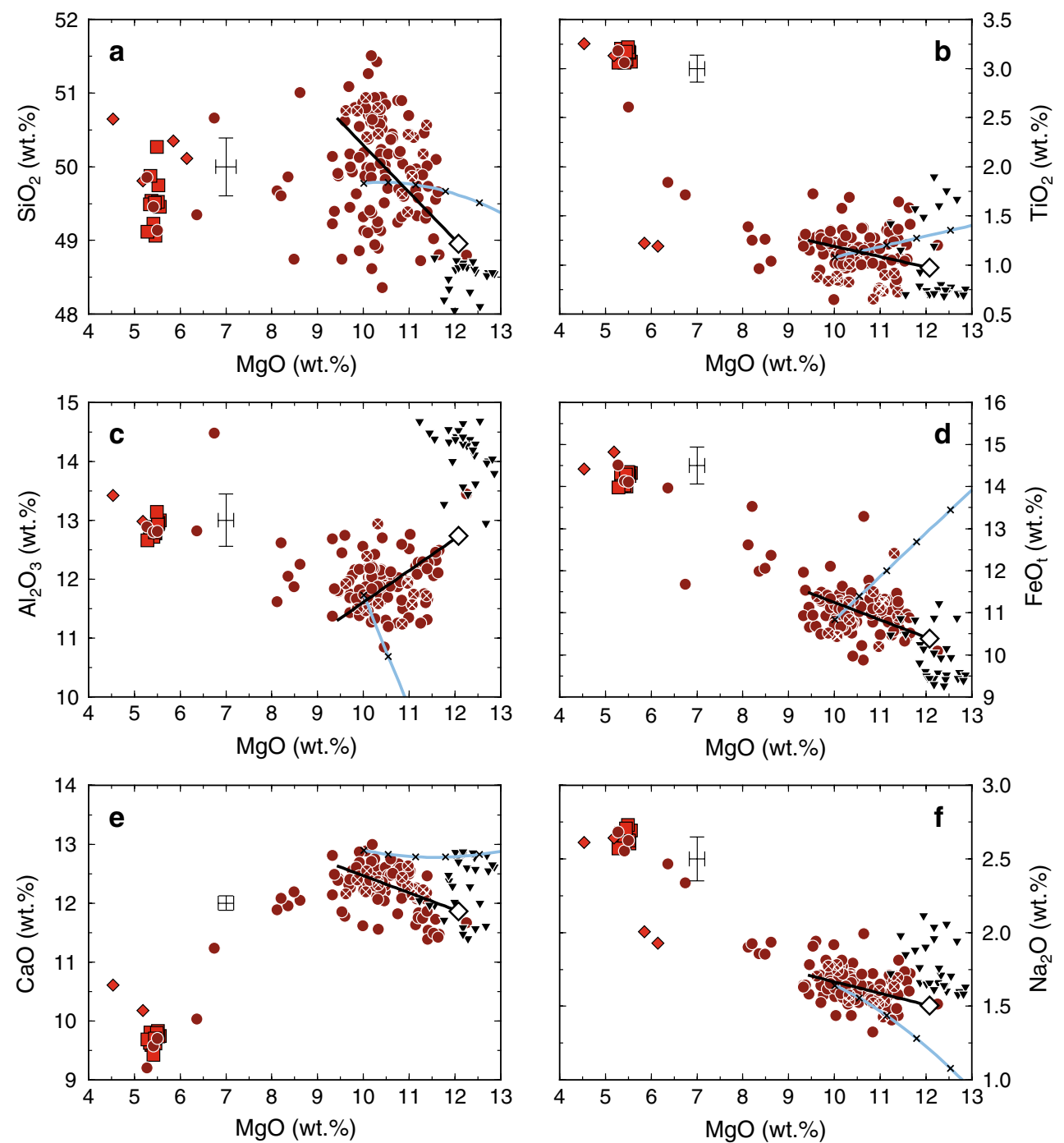

\begin{tabular}{|ll|}
\hline - PC1 (9.5-12 wt.\% MgO): plg:ol:cpx = 13:7:0 & $\bullet$ plg-hosted MI \\
* plagioclase PEC path with 5\% intervals & $\diamond$ low-HFSE MI \\
$\diamond$ hypothetical near-primary melt & $\diamond$ ol-hosted MI \\
$\checkmark$ best fitting primitive Icelandic melts & $\square$ matrix glasses \\
\hline
\end{tabular}

Fig. 4 Plots summarising melt inclusion and matrix glass major element compositions from the Saksunarvatn tephra. $2 \sigma$ error bars are shown throughout. Melt inclusion compositions have not been corrected for post-entrapment crystallisation (PEC). The first principal component $(\mathrm{PC} 1)$ of primitive melt inclusion major element data $(9.5$ $\mathrm{wt} \%<\mathrm{MgO}<12 \mathrm{wt} \%$ ) is shown by the solid black line. The composition of a hypothetical near-primary melt $(\mathrm{Mg} \#=70)$ is shown by the large open diamond. Variation along PC1 can be accounted for by removing a troctolitic assemblage consisting of plg:ol:cpx in a 13:7:0 ratio from the hypothetical near-primary melt. PEC (black crosses mark $5 \%$ PEC intervals) moves plagioclase-hosted melt inclusion compositions along the solid blue line. $\mathrm{Al}_{2} \mathrm{O}_{3}(\mathbf{c})$ and $\mathrm{FeO}_{\mathrm{t}}(\mathbf{d})$, which are particularly sensitive to PEC, show little evidence of post-entrapment modification. Natural Icelandic compositions that most closely match the hypothetical near-primary melt are shown as inverted black triangles (Slater et al. 2001; Maclennan et al. 2003) an estimate of analytical error (Maclennan et al. 2003)) in excess of 1.71 (Fig. 6). $\mathrm{La} / \mathrm{Yb}, \mathrm{La} / \mathrm{Sm}$ and $\mathrm{Sr} / \mathrm{Sr}^{*}$ are also significantly variable at the $99 \%$ confidence level, and $\mathrm{Sm} / \mathrm{Yb}$ values are significantly variable at the $95 \%$ confidence level.

Some primitive melt inclusions have striking high-field strength element (HFSE) (Fig. 6). In contrast to the full primitive melt inclusion population, HFSE-depleted melt inclusions have lower mean concentrations of moderately incompatible trace elements (Fig. 5c) and are also slightly more incompatible trace element-enriched (HFSE-depleted mean La/ $\mathrm{Yb}=2.51 \pm 0.58(1 \sigma)$ versus $\mathrm{La} / \mathrm{Yb}=1.95 \pm 0.61(1 \sigma))$.

\section{$\mathrm{H}_{2} \mathrm{O}$ and $\mathrm{CO}_{2}$}

Matrix glass and melt inclusion $\mathrm{H}_{2} \mathrm{O}-\mathrm{CO}_{2}$ systematics are summarised in Fig. 7a. The $\mathrm{CO}_{2}$ content of primitive melt 

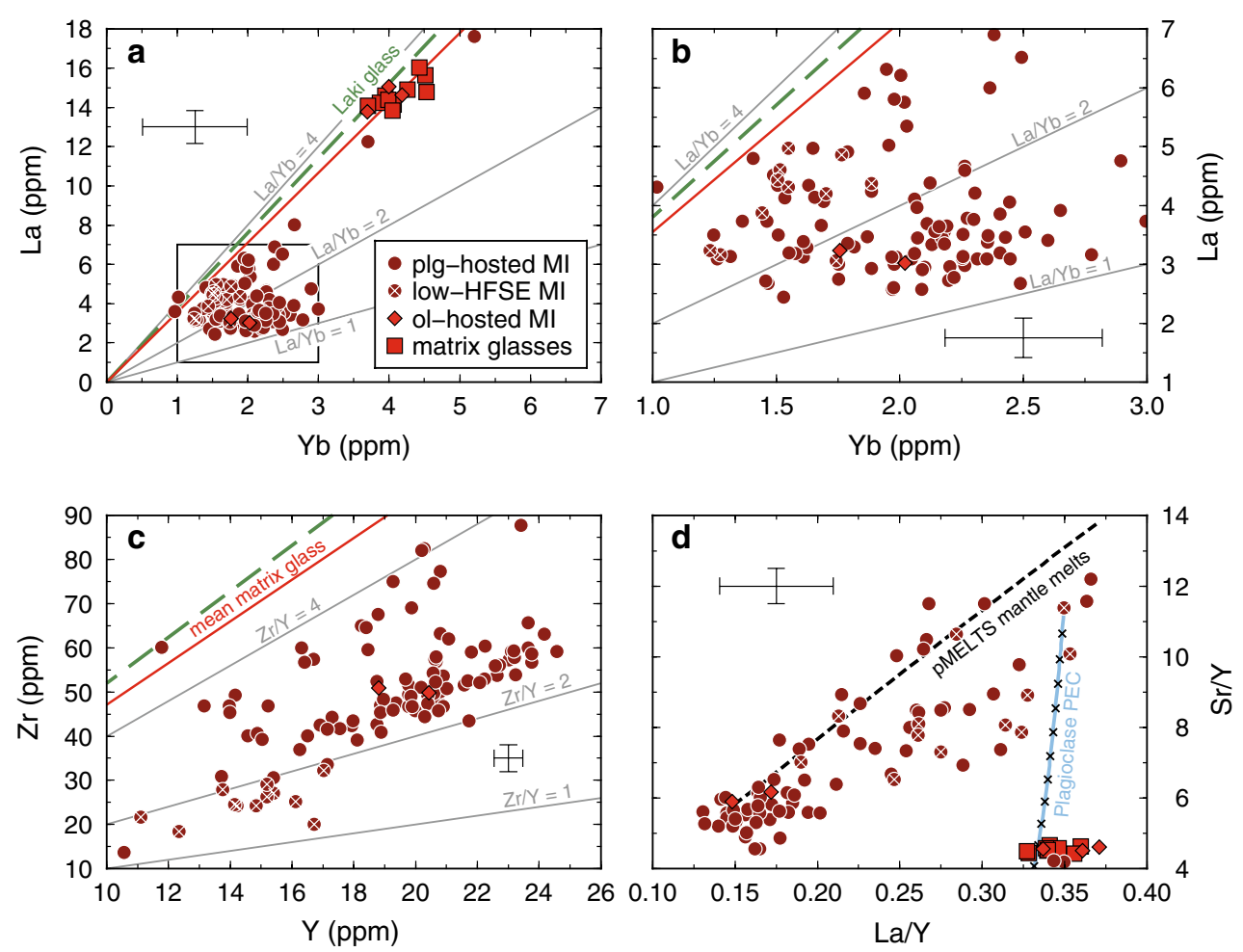

Fig. 5 Plots summarising melt inclusion and matrix glass trace element compositions from the Saksunarvatn tephra. $2 \sigma$ error bars are shown. a Plot of highly incompatible La versus moderately incompatible $\mathrm{Yb}$. The mean $\mathrm{La} / \mathrm{Yb}$ of matrix glass compositions is plotted as a solid red line. The mean matrix glass composition from the Laki eruption (Hartley et al. 2014) is shown as a dashed green line. Lines of constant ratio are shown as solid pale grey lines. The black box shows the region plotted in (b). b La plotted against $\mathrm{Yb}$ at an expanded scale to show primitive melt inclusion compositions with greater clarity. Low-HFSE melt inclusions are relatively incompatible trace element-enriched $(\mathrm{La} / \mathrm{Yb}>2)$. c Plot of more incompatible $\mathrm{Zr}$ versus less incompatible Y. Low-HFSE melt inclusions have distinc-

inclusions ranges from 262 to $2070 \mathrm{ppm}$. Evolved melt inclusions contain $78-405 \mathrm{ppm} \mathrm{CO}_{2}$. All values $<200 \mathrm{ppm}$ are found in olivine-hosted melt inclusions. The $\mathrm{CO}_{2}$ content of the matrix glass is below the detection limit of $\mathrm{CO}_{2}$ by SIMS $(\sim 25 \mathrm{ppm})$. The $\mathrm{H}_{2} \mathrm{O}$ content of primitive melt inclusions ranges from 0.19 to $0.64 \mathrm{wt} \%$, though most inclusions contain $>0.4 \mathrm{wt} \% \mathrm{H}_{2} \mathrm{O}$. Evolved melt inclusions are $\mathrm{H}_{2} \mathrm{O}$-rich, containing $0.56-0.68 \mathrm{wt} \% \mathrm{H}_{2} \mathrm{O}$. Matrix glass $\mathrm{H}_{2} \mathrm{O}$ contents span the range $0.11-0.46 \mathrm{wt} \% \mathrm{H}_{2} \mathrm{O}$.

\section{Inclusion-hosted bubbles}

If inclusion-hosted bubbles remain in equilibrium with coexisting trapped melts during cooling; then, $\mathrm{CO}_{2}$ may be transferred into inclusion-hosted bubbles (Roedder 1979; Anderson and Brown 1993; Steele-Macinnis et al. 2011; Bucholz et al. 2013; Hartley et al. 2014; Moore et al. 2015). However, assuming that bubble-melt tively low $\mathrm{Zr} / \mathrm{Y}$ values in comparison with the rest of the primitive melt inclusion population. Evolved melt inclusions and the matrix glass have higher $\mathrm{Zr}$ and $\mathrm{Y}$ contents than shown on this figure. d Plot of $\mathrm{Sr} / \mathrm{Y}$ versus La/Y. Primitive melt inclusions define a positively correlated array. Instantaneous fractional melt compositions calculated using pMELTS (Ghiorso et al. 2002) shown as a dashed black line. Melting calculations were performed using a depleted MORB mantle source (DMM; Workman and Hart 2005). Plagioclase PEC, shown as a solid pale blue line, affects $\mathrm{Sr} / \mathrm{Y}$, but not La/Y. Evolved melt inclusions and the matrix glass have low $\mathrm{Sr} / \mathrm{Y}$, consistent with substantial crystallisation of plagioclase during melt evolution

equilibrium is maintained within cooling, inclusions may not always be valid: rapid quenching kinetically inhibits $\mathrm{CO}_{2}$ diffusion, resulting in reduced sequestration of $\mathrm{CO}_{2}$ into bubbles (Neave et al. 2014a; Wallace et al. 2015).

Inclusion-hosted bubbles are present in 49 of the 133 melt inclusions analysed from the Hvítárvatn tephra layer. The majority of inclusion-hosted bubbles make up $3.0 \pm 1.5(1 \sigma)$ vol. \% of total melt inclusion volumes, consistent with formation by thermal contraction (Lowenstern 1995; Moore et al. 2015). In three inclusions, bubbles make up larger proportions (8-12 vol. \%), consistent with simultaneous entrapment alongside the silicate melt. No Fermi doublets were detected in the subset of inclusion-hosted bubbles investigated by Raman spectroscopy, indicating that that minimal $\mathrm{CO}_{2}$ currently resides within inclusion-hosted bubbles $(<0.04 \mathrm{~g} /$ $\mathrm{cm}^{3}$ ). That glasses from bubble-bearing and bubble-free 


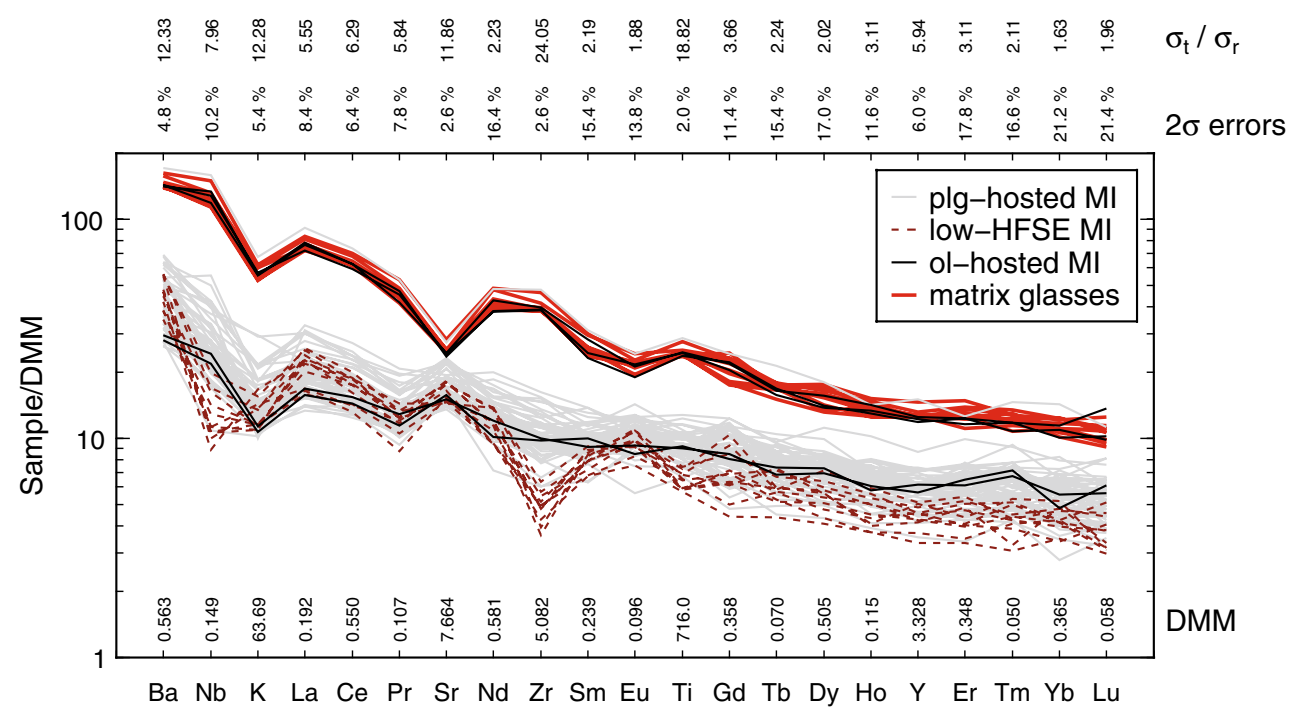

Fig. 6 Depleted MORB mantle (DMM; Workman and Hart 2005) normalised multi-element diagram for melt inclusions and the matrix glass from the Saksunarvatn tephra. Melt inclusion compositions fall into two populations: an evolved population that contains the matrix glass and a few melt inclusions hosted in plagioclase and olivine, and a primitive population that contains the majority of plagioclase-hosted melt inclusions and two olivine-hosted melt inclusions. $2 \sigma$ errors are shown along the top of the plot and DMM normalisation values are shown along the bottom. Variability in primitive plagioclase-hosted melt inclusions is reported as signal-tonoise ratios $\left(\sigma_{t} / \sigma_{\mathrm{r}}\right)$ for each element measured along the top of the plot (e.g. Maclennan et al. 2003). All trace elements apart from $\mathrm{Yb}$ have $\sigma_{\mathrm{t}} / \sigma_{\mathrm{r}}$ values that are significant at the $99 \%$ confidence level (i.e. $\left.\sigma_{\mathrm{t}} / \sigma_{\mathrm{r}}>1.71\right)$. A sub-population of plagioclase-hosted melt inclusions, plotted as dashed red lines, have pronounced high-field strength element (HFSE) depletions that are particularly visible as negative $\mathrm{Nb}$ and $\mathrm{Zr}$ anomalies; low-HFSE melt inclusions have $\mathrm{Zr} / \mathrm{Y}<2$ (Fig. 5c)

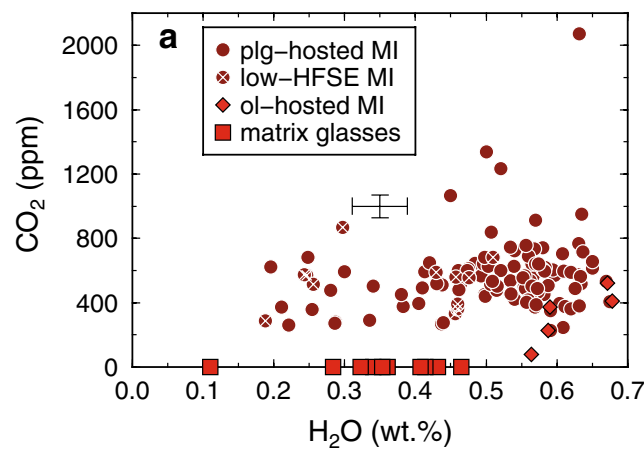

Fig. 7 a Plot summarising melt inclusion and matrix glass $\mathrm{H}_{2} \mathrm{O}$ and $\mathrm{CO}_{2}$ contents. $2 \sigma$ error bars are shown. b Cumulative probability distributions of $\mathrm{CO}_{2}$ in bubble-bearing and bubble-free primitive plagioclase-hosted melt inclusion populations. Bubble-bearing and

melt inclusion populations have similar $\mathrm{CO}_{2}$ composition distributions further suggests that sequestration of $\mathrm{CO}_{2}$ into inclusion-hosted bubbles has not occurred and that these near-vacuum bubbles contain, at most, noble gases and trace amounts of $\mathrm{CO}_{2}$ (Fig. 7b; Neave et al. 2014a) Whilst we conclude that inclusion glasses record the total $\mathrm{CO}_{2}$ content of melt inclusions at the time of quenching, our findings are unaffected if bubble-bearing inclusions are removed from the data set.

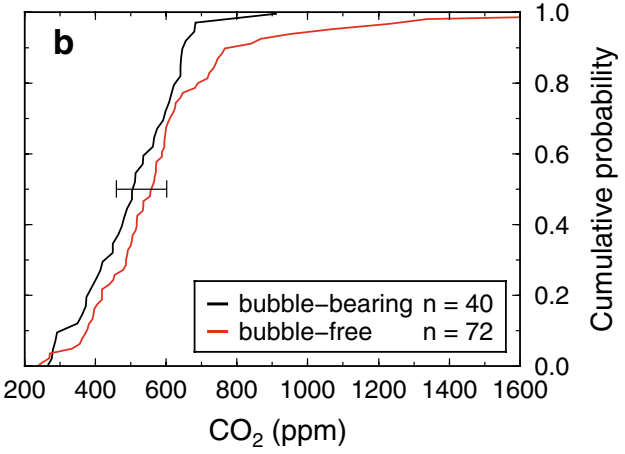

bubble-free inclusions have similar $\mathrm{CO}_{2}$ distributions, indicating that bubbles contain negligible $\mathrm{CO}_{2}$. Note that bubble-free inclusions are systematically offset to slightly higher values by a small population of low- $\mathrm{CO}_{2}(<300 \mathrm{ppm})$ bubble-bearing inclusions

\section{Discussion}

\section{Provenance of the tephra}

Hvitárvatn tephra glass compositions overlap with those from the Grímsvötn volcanic system (Fig. 8; Sigmarsson et al. 2000, 2013; Jude-Eton et al. 2012; Streeter and Dugmore 2014), with strombolian tephra glasses from the AD 1783-1784 Laki eruption providing the closest match 
(Thordarson et al. 1996; Hartley et al. 2014). In contrast, glasses from the Bárðarbunga-Veiðivötn system are more primitive and incompatible trace element-depleted than the Hvítárvatn tephra layer (Hansen and Grönvold 2000; Lawson et al. 2007; Neave et al. 2014a; Streeter and Dugmore 2014), whereas those from the Katla system are more evolved and incompatible trace element-enriched (Óladóttir et al. 2007).

The presence of blocky and modestly vesiculated sideromelane glass within the Hvítárvatn samples suggests that magma-ice interactions occurred during eruption and may have contributed to an explosive eruption style (Jóhannsdóttir et al. 2005). During subglacial eruptions, rapid quenching restricts the exsolution of moderately soluble volatile species such as $\mathrm{H}_{2} \mathrm{O}$ and $\mathrm{S}$, resulting in subglacially erupted tephras retaining higher volatile contents than their subaerial counterparts (Moore and Calk 1991; Óladottir et al. 2007; Tuffen et al. 2010). The most evolved melt inclusions from the Hvítárvatn tephra layer contain $0.60 \pm 0.04(1 \sigma) \mathrm{wt} \% \mathrm{H}_{2} \mathrm{O}$ and provide the best estimate of immediately pre-eruptive $\mathrm{H}_{2} \mathrm{O}$ content. Tephra glass $\mathrm{H}_{2} \mathrm{O}$ contents of $0.11-0.46 \mathrm{wt} \%(0.26-3.21 \mathrm{MPa}$ using the model of Shishkina et al. 2014) are significantly higher than strombolian tephra glass $\mathrm{H}_{2} \mathrm{O}$ contents from the AD 1783-1784 Laki eruption $(0.08 \pm 0.01 \mathrm{wt} \%$; Hartley et al. 2014) and indicate that $\mathrm{H}_{2} \mathrm{O}$ exsolution prior to solidification was incomplete, consistent with the subglacial, and possibly phreatoplinian, eruption style suggested by Jóhannsdóttir et al. (2005).

\section{Crystal-melt relationships}

Macrocryst rims $\left(\sim \mathrm{An}_{65}, \mathrm{Mg} \#_{\mathrm{cpx}} \sim 73, \sim \mathrm{Fo}_{72.5}\right)$ are in equilibrium with the matrix glass according to the following mineral-melt equilibrium models: Namur et al. (2011) for plagioclase, Herzberg and O'Hara (2002) for olivine and Eq. 35 of Putirka (2008) for clinopyroxene (Fig. 3). A ferric to total iron ratio $\left(\mathrm{Fe}^{3+} / \Sigma \mathrm{Fe}\right)$ of 0.1 (i.e. $f \mathrm{O}_{2} \sim \mathrm{QFM}-1$; Maclennan 2008a, b) was assumed on the basis that it lies within the range of measured Icelandic basalts $(0.08-0132$; Breddam 2002; Óskarsson et al. 1994). It is thus likely that evolved macrocrysts $\left(\mathrm{An}_{60^{-}}-\mathrm{An}_{68}, \mathrm{Mg \#} \#_{\mathrm{cpx}}=71-78, \mathrm{Fo}_{70^{-}}\right.$ $\mathrm{Fo}_{76}$ ) crystallised from melts directly parental to the matrix glass. Melt inclusions hosted within evolved plagioclase and olivine macrocrysts have very similar trace element ratios to the matrix glass, indicating that they are related by evolution along a single liquid line of descent (Fig. 5a).

Compositional relationships between clinopyroxene macrocrysts and the matrix glass were investigated using analyses of trace elements within clinopyroxene macrocrysts. Following the methods of Winpenny and Maclennan (2011) and Neave et al. (2014b), La/ $\mathrm{Yb}_{\mathrm{cpx}}$ values were converted into $\mathrm{La} / \mathrm{Yb}_{\text {melt }}$ values using appropriate

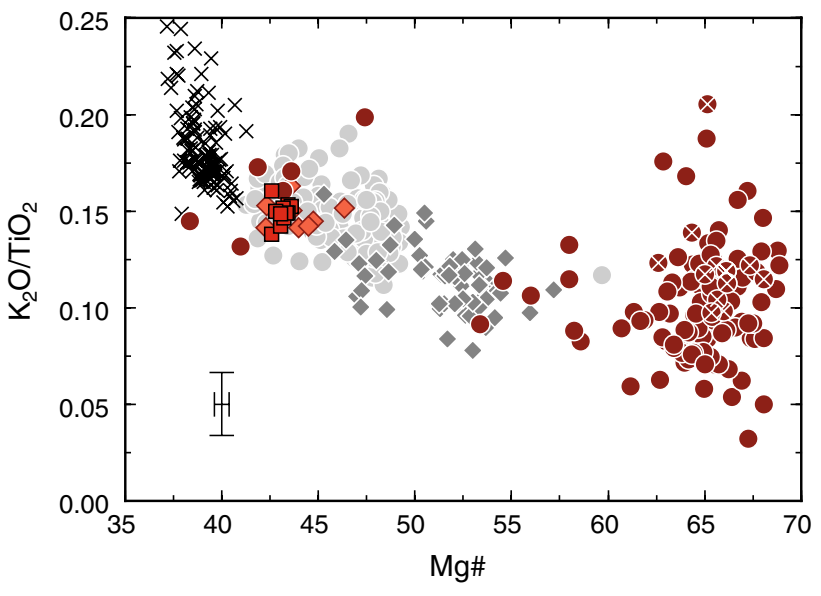

* Hvítárvatn tephra layer matrix glass
Hvítárvatn tephra MI
* Hvítárvatn tephra MI (low-HFSE)
Literature values
$\diamond$ Saksunarvatn ash Grímsvötn
Veiðivötn $\quad \times$ Katla

Fig. 8 Plot comparing the major element compositions of Hvítárvatn tephra layer glasses and melt inclusions with literature values for the Saksunarvatn ash and other EVZ eruptions according to their $\mathrm{Mg \#}$ and $\mathrm{K}_{2} \mathrm{O} / \mathrm{TiO}_{2}$ contents. Literature values for the Saksunarvatn ash were taken from the following sources representing the full geographic coverage: Mangerud et al. (1986); Sigurgeirsson and Leósson (1993); Grönvold et al. (1995); Björck et al. (1992); and BramhamLaw et al. (2013). Glass compositions from the Grímsvötn volcanic system were taken from Thordarson et al. (1996), Sigmarsson et al. (2000), Jude-Eton et al. (2012), Hartley et al. (2014) and Streeter and Dugmore (2014). Glass compositions from the BárðarbungaVeiðivötn system were taken from Hansen and Grönvold (2000), Lawson et al. (2007), Neave et al. (2014a) and Streeter and Dugmore (2014). Glass compositions from the Katla system were taken from Óladóttir et al. (2007)

pressure-temperature-composition $\quad(\mathrm{P}-\mathrm{T}-\mathrm{X})$-dependent partition coefficients (Wood and Blundy 1997). Appropriate pressures and temperatures were selected using the results of thermobarometric calculations discussed in later sections. $\mathrm{La} / \mathrm{Yb}$ eqm values were only calculated for clinopyroxene zones that maintained crystal-melt equilibrium during growth. By calculating equilibrium ratios instead of equilibrium abundances, most errors associated with calculating partition coefficients cancel out because of the form of the Brice equation for lattice strain (Brice 1975). Uncertainties are discussed further by Winpenny and Maclennan (2011) and Neave et al. (2014b).

$\mathrm{La} / \mathrm{Yb}_{\text {melt }}$ values calculated from clinopyroxene macrocrysts are shown alongside melt inclusion and matrix glass compositions in Fig. 9. The trace element composition of low-Mg\# clinopyroxenes is consistent with crystallisation alongside low-anorthite plagioclase and low-forsterite olivine from melts closely related to the matrix glass (La/ $\left.\mathrm{Yb}_{\text {melt }} \sim 3.6\right)$. Furthermore, all evolved macrocryst phases 


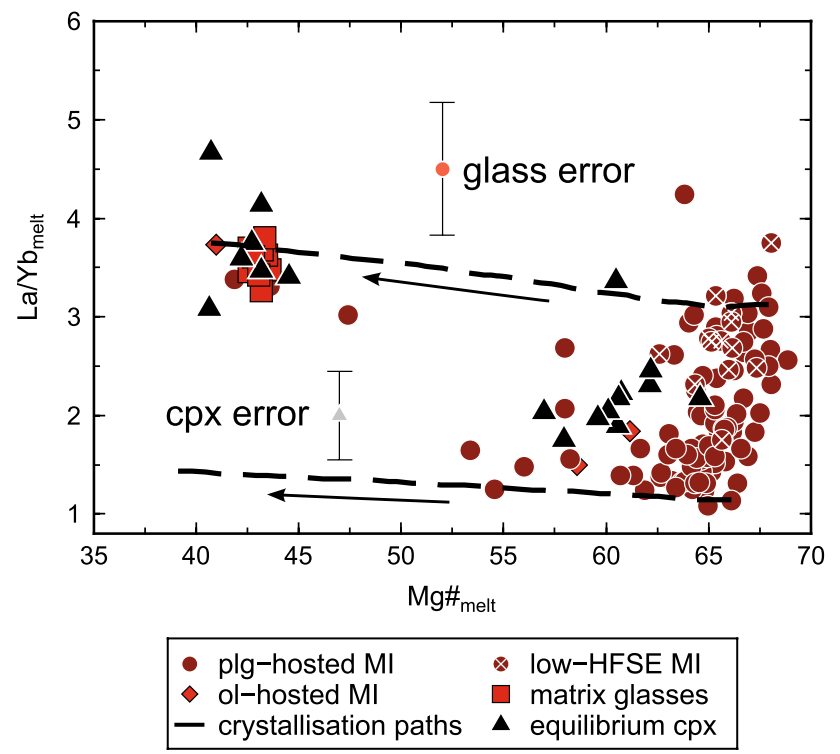

Fig. $9 \mathrm{La} / \mathrm{Yb}$ versus $\mathrm{Mg \#}_{\text {melt }}$ for melts calculated to be in equilibrium with clinopyroxene macrocryst cores, melt inclusions and the matrix glass. REE partition coefficients were calculated at appropriate P-T-X conditions using Wood and Blundy (1997). The Mg\# of melts in equilibrium with clinopyroxene macrocrysts was determined using $K_{d \text { Fe-Mg }}^{\text {cpx-liq }}$ values from Eq. 35 of Putirka (2008). The $2 \sigma$ error of $\mathrm{La} / \mathrm{Yb}_{\text {melt }}$ in equilibrium with clinopyroxene macrocrysts was estimated by calculating equilibrium melts for multiple analyses within an individual macrocryst zone. Dashed black lines show fractional crystallisation paths from typical primitive incompatible trace element-depleted and trace element-enriched melt inclusion compositions calculated using Petrolog (Danyushevsky and Plechov 2011) and appropriate partition coefficients (Hart and Dunn 1993; Beattie 1994; Aigner-Torres et al. 2007). Calculations were performed at a pressure of 3 kbar with $f \mathrm{O}_{2}$ buffered at QFM-1

show either skeletal textures or sector zoning that are consistent with rapid cooling rates (Nakamura 1973; Lofgren 1974; Welsch et al. 2013). In contrast, La/ $\mathrm{Yb}_{\text {melt }}$ values calculated from high-Mg\# clinopyroxenes are significantly more depleted in incompatible trace elements $(\mathrm{La} /$ $\left.\mathrm{Yb}_{\text {melt }}=1.75-3.34\right)$ and lie within the La/Yb range of the primitive melt inclusions.

Trace element disequilibrium between primitive melt inclusions (mean $\mathrm{La} / \mathrm{Yb}=2.07$ ) and high-Mg\# clinopyroxenes (mean $\mathrm{La} / \mathrm{Yb}_{\text {melt }}=2.22$ ) on the one hand, and evolved melt inclusions, low-Mg\# clinopyroxenes and the matrix glass on the other (mean La/ $/ \mathrm{bb}_{\text {melt }}=3.55$ ) indicates that most primitive macrocrysts cannot be related to the matrix glass by a single liquid line of descent. Fractional crystallisation paths calculated for representative incompatible trace element-depleted and enriched primitive melt inclusions using Petrolog (Danyushevsky and Plechov 2011) with appropriate partition coefficients (Hart and Dunn 1993; Beattie 1994; Aigner-Torres et al. 2007) demonstrate that, whilst the most enriched primitive melt inclusions could evolve to be in trace element equilibrium with the matrix glass, most inclusions would remain too depleted (Fig. 8). Trace element variability between primitive and evolved components of the Hvitárvatn tephra layer thus reflects the growth of these two assemblages from different distributions of compositionally diverse mantle melts (Gurenko and Chaussidon 1995; Slater et al. 2001). Similar relationships between incompatible trace element enrichment and degree of evolution have been reported in samples across the EVZ, where they have been interpreted as a signal of mixing of primitive crystal mushes into evolved melts shortly before eruption (Hansen and Grönvold 2000; Halldórsson et al. 2008; Passmore et al. 2012; Neave et al. 2014b).

Conversion of $\mathrm{Mg \#}_{\mathrm{cpx}}$ to $\mathrm{Mg \#}_{\text {melt }}$ using $K_{d \mathrm{Fe}-\mathrm{Mg}}^{\mathrm{cpx}-\mathrm{liq}}$ from Eq. 35 of Putirka (2008) shows that only some primitive melt inclusions were three-phase saturated at the time of entrapment: high-Mg\# clinopyroxene macrocrysts $\left(\mathrm{Mg} \#_{\mathrm{cpx}}=82-87\right)$ are in equilibrium with $\mathrm{Mg \#} \#_{\text {melt }}=57-65$, implying that inclusions with $\mathrm{Mg \#} \#_{\text {melt }}>65$ were not in saturated in clinopyroxene at the time of their entrapment. The appearance of clinopyroxene on the liquidus after olivine and plagioclase is nevertheless consistent with observations from petrologically similar systems from the EVZ (Hansen and Grönvold 2000; Neave et al. 2013, 2014b).

\section{Geochemical variability in primitive plagioclase-hosted melt inclusions}

\section{Post-entrapment crystallisation}

Melt inclusions hosted in high-anorthite plagioclase crystals can preserve comparable records of geochemical variability to those hosted in high-forsterite olivine (Sours-Page et al. 2002). However, before interpreting melt inclusion compositions in terms of primary magmatic processes, it is important to determine, and if necessary correct for, the effects of post-entrapment processes on inclusion compositions (e.g. Danyushevsky et al. 2000; Cottrell et al. 2002).

Post-entrapment crystallisation (PEC) paths were calculated using a forward model by incrementally crystallising plagioclase from representative inclusion compositions (blue lines on Figs. 4, 5d). Plagioclase major and trace element contents were calculated using Eq. 33 of Namur et al. (2011) with $\mathrm{T}-\mathrm{X}$ dependent partition coefficients from Blundy and Wood $(1991,1994)$ and Bédard (2006). Calculated PEC paths reproduce the coupled $\mathrm{Al}_{2} \mathrm{O}_{3}-\mathrm{Sr}$ depletion and $\mathrm{TiO}_{2}-\mathrm{FeO}_{\mathrm{t}}-\mathrm{REE}$ enrichment observed in natural samples that have experienced PEC (Nielsen 1995; Nielsen 2011), but lie at high angles to melt inclusion trends from the Hvítárvatn tephra layer (Figs. 4, 5d). The effect of PEC on this inclusion suite has thus been minimal, and no PEC corrections were applied. 


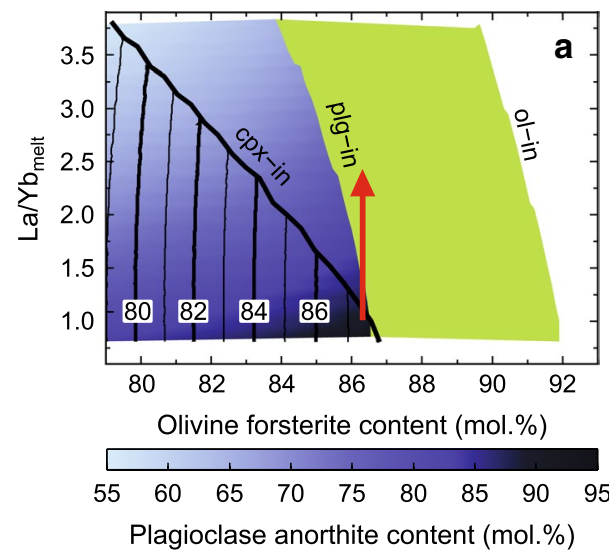

Fig. 10 a Plot demonstrating how the stability and composition of olivine, plagioclase and clinopyroxene vary during the crystallisation of different Icelandic primary melts. Clinopyroxene $\mathrm{Mg \#}$ is shown as black contours within the clinopyroxene-present field. Crystallisation calculations were performed at a pressure of $3 \mathrm{kbar}$ with $f \mathrm{O}_{2}$ buffered at QFM-1 using Petrolog (Danyushevsky and Plechov 2011). Major element starting compositions were generated by linear mixing of the experimental melts from Walter (1998) and Kogiso et al. (1998) that were identified by Shorttle and Maclennan (2011) as potential depleted and enriched primary melts for Iceland. Trace element ratios were taken from Shorttle and Maclennan (2011). High-anorthite

\section{Trace element variability and high-field strength element depletion}

It is well established that primitive melt inclusions record the supply of diverse primary melts to magma reservoirs (Sobolev and Shimizu 1993; Nielsen 1995; Maclennan 2008a). It follows that most variability in melt inclusion and clinopyroxene trace element ratios from the Hvítárvatn tephra layer reflects the supply of compositionally heterogeneous primitive melts to the base of the Grímsvötn volcanic system (Gurenko and Chaussidon 1995; Maclennan 2008b). For example, strong positive correlations between $\mathrm{Sr}$ and highly incompatible trace elements such as $\mathrm{La}$ and $\mathrm{Ce}(r \geq 0.80)$ can be accounted for by melting of aluminous lherzolite within the garnet stability field (e.g. McKenzie and O'Nions 1991), as illustrated by the range of pMELTSderived incremental fractional melt compositions shown in Fig. 5d (Ghiorso et al. 2002). However, HFSE depletions present in a subset of plagioclase-hosted melt inclusions cannot be explained by simple mantle melting processes alone.

Following Nakamura and Shimakita (1998), Michael et al. (2002) proposed that HFSE depletion in plagioclasehosted melt inclusions can result from the slow diffusion of these elements into melt channels formed by plagioclase dissolution that subsequently seal to form melt inclusions. The inclusion-rich, sieve-like texture of plagioclase macrocrysts in the Hvítárvatn tephra layer that host

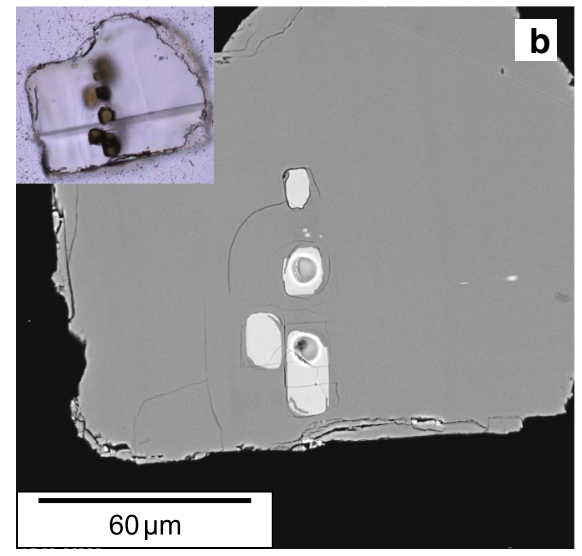

plagioclase and high-Mg\# clinopyroxene are only stable in low-La/ $\mathrm{Yb}$, high- $\mathrm{Ca} / \mathrm{Na}$ melts. Transfer of high-anorthite macrocrysts into incompatible trace element-enriched and plagioclase-undersaturated melts by mixing, as indicated by the red arrow, may result in HFSEdepleted melt inclusion formation by crystal dissolution. b BSE image showing a string of aligned melt inclusions that may represent re-annealed melt channels within plagioclase macrocryst cores. Circular features are pits formed during SIMS analyses. A transmitted light photomicrograph of the same grain showing the discrete nature of melt inclusions is shown in the top left

HFSE-depleted inclusions is consistent with inclusion formation by dissolution (Fig. 2b).

Phase equilibria experiments demonstrate that highanorthite plagioclase is only stable in $\mathrm{H}_{2} \mathrm{O}$-poor basalts when melt $\mathrm{Ca} / \mathrm{Na}$ contents are high (Duncan and Green 1987; Panjasawatwong et al. 1995). In their survey of primitive melts from Iceland, Shorttle and Maclennan (2011) showed that incompatible trace element enrichment correlates negatively with $\mathrm{Ca} / \mathrm{Na}$ in basalts of constant $\mathrm{MgO}$. It follows that the stability of high-anorthite plagioclase in primitive basalts also correlates negatively with the degree of incompatible trace element enrichment. Crystallisation calculations performed at $3 \mathrm{kbar}$ with $f \mathrm{O}_{2}$ buffered at QFM-1 using Petrolog (Danyushevsky and Plechov, 2011) confirm that high-anorthite plagioclase $\left(>\mathrm{An}_{85}\right)$ only crystallises from the most incompatible trace element-depleted primitive liquids (Fig. 10a). Starting compositions for these Petrolog calculations were generated by mixing the experimental melts from Walter (1998) and Kogiso et al. (1998) that Shorttle and Maclennan (2011) identified as potential depleted and enriched primary melt compositions for Iceland.

We suggest that high-anorthite macrocrysts, which initially crystallised from high- $\mathrm{Ca} / \mathrm{Na}$, low-La/ $\mathrm{Yb}$ melts, subsequently became unstable following juxtaposition against low- $\mathrm{Ca} / \mathrm{Na}$, high- $\mathrm{La} / \mathrm{Yb}$ and plagioclase-undersaturated melts. Such a juxtaposition could occur via convective stirring in magma reservoirs (Maclennan 2008b), or 
by flushing melts of variable composition through porous crystal mushes (Danyushevsky et al. 2003). These melt channels formed by plagioclase dissolution would then start to re-equilibrate with these plagioclase-undersaturated liquids. Melt channels would ultimately seal once the surrounding liquid became plagioclase-saturated again, whether by mixing or differentiation, and low-HFSE, high$\mathrm{La} / \mathrm{Yb}$ melt inclusions would be formed as a result. Elongate, strung-out chains of melt inclusions in high-anorthite cores may thus represent partially re-annealed melt channels (Fig. 10b). It is important to note that HFSE-undepleted inclusions may have also formed by dissolution, given that complete re-equilibration of HFSEs prior to entrapment can be achieved within hours under magmatic conditions (LaTourrette et al. 1996). Thus, although inclusions may not represent the melts from which their highanorthite hosts initially crystallised, most primitive plagioclase-hosted melt inclusions nevertheless preserve a record of mantle-derived trace element variability.

\section{Differentiation of primitive melts recorded in melt inclusion major element compositions}

Although much of the trace element (i.e. $\mathrm{La} / \mathrm{Yb}$ ) variability in primitive melt inclusions from the Hvitárvatn tephra layer can be accounted for by mantle melting and subsequent mixing (e.g. Maclennan 2008b), these processes are unable to account for all major element diversity. For example, significant variability in primitive plagioclasehosted melt inclusion $\mathrm{Mg \#}$ contents $\left(\sigma_{\mathrm{t}} / \sigma_{\mathrm{r}}=10.1\right)$ suggests that major element compositions have been modified by fractionation controlled by ferromagnesian minerals.

Fitting liquid lines of descent between primitive and evolved end-member melt compositions using least-squares methods are a well-established technique for assessing the relative importance of different phases during melt evolution (Wright and Doherty 1970). However, by fitting the first principal component axis (PC1) of a whole data set it is possible to constrain crystallising phase proportions without having to select primitive and evolved end-members a priori (Maclennan et al. 2001; Neave et al. 2012). PC1 was identified in the Hvítárvatn data set by performing principal component analysis (PCA) on inclusions with $\mathrm{MgO}>9.5$ wt\% $(\mathrm{Mg} \#>62)$ in the system $\mathrm{SiO}_{2}-\mathrm{TiO}_{2}-\mathrm{Al}_{2} \mathrm{O}_{3}-\mathrm{FeO}_{\mathrm{t}}-$ $\mathrm{MgO}-\mathrm{CaO}-\mathrm{Na}_{2} \mathrm{O}-\mathrm{K}_{2} \mathrm{O}$ (CFNKTMAS). Least-squares fits were then calculated using mean primitive plagioclase, olivine and clinopyroxene compositions.

The best-fitting average liquid line of descent (RMS error $=0.22$ ) indicates that plagioclase, olivine and clinopyroxene crystallised in the ratio 13:7:0. However, PC1 only accounts for $44 \%$ of the total variance in the data set. PC2, which accounts for $23 \%$ of the data set's variance, is fitted best by crystallisation of plagioclase, olivine and clinopyroxene in the ratio 5:4:11 (RMS error $=0.23)$. Thus, whilst melt inclusion compositions are dominantly controlled by crystallisation of a troctolitic assemblage, evidence of clinopyroxene crystallisation, most likely from the lowest Mg\# primitive melts, is nevertheless recorded. That PC1 and PC2 only account for $67 \%$ of the total variance reflects the combined effects of analytical error, primary melt heterogeneity and PEC on major element variation.

\section{Primary melts from the EVZ}

A hypothetical, near-primary melt composition, marked on Fig. 4 as a white diamond, was calculated by adding primitive plagioclase and olivine into the mean primitive plagioclase-hosted melt inclusion composition in a 13:7 ratio until $\mathrm{Mg} \#_{\text {melt }}$ reached $70 . \mathrm{Mg} \#=70$ represents a commonly assumed minimum value for MORB primary melts (Kinzler and Grove 1992) and lies in within the Icelandic primary melt Mg\# range estimated by Shorttle and Maclennan (2011): $66-73$ at $\mathrm{MgO}=11.1 \mathrm{wt} \%$. Whilst this hypothetical melt does not represent a unique primary melt composition for either the $10 \mathrm{ka}$ Grímsvötn tephra series or the $\mathrm{EVZ}$, it does enable a previously elusive near-primary melt composition from EVZ to be compared quantitatively with magma compositions from elsewhere in Iceland.

Major elements in the hypothetical near-primary melt lie largely within the $2 \sigma$ error of most primitive melt inclusion analyses (Fig. 4). The near-primary melt composition was compared with a large $(n=3480)$ database of Icelandic whole-rock and glass compositions (see Appendix 1 of Shorttle and Maclennan (2011), with further additions from Koornneef et al. (2012)). Absolute differences between oxides (in wt $\%)$ in the hypothetical primary melt $\left(w^{x}\right)$ and database entries $\left(w^{i}\right)$ were summed to give a total misfit $(M)$ as follows:

$M=\sum_{i}\left|w_{i}^{x}-w_{i}^{0}\right|$

where $i$ refers to an oxide in the CFNKTMAS system. Whole-rock compositions from the Borgarhraun flow in the Theistareykir system of the NVZ (Fig. 1; Maclennan et al. 2003) consistently return the lowest misfits $(M<4.5)$ and are shown in Fig. 4. Whole-rock samples from Borgarhraun also have $\mathrm{La} / \mathrm{Yb}$ values of $\sim 1.2$ that lie within the range defined by primitive inclusions from Hvítárvatn (Maclennan et al. 2003). Eruptions from within the Brennisteinsfjöll volcanic system on the Reykjanes Peninsula also provide close matches (Fig. 1). However, most natural compositions from the $\mathrm{NVZ}$ have $\mathrm{Al}_{2} \mathrm{O}_{3}$ and $\mathrm{CaO}$ contents that are $1-1.5 \mathrm{wt} \%$ higher than the hypothetical melt. Explanations for these discrepancies include plagioclase accumulation in Borgarhraun whole-rock samples or plagioclase crystallisation within primitive inclusions from Hvítárvatn. 
Nevertheless, similarities between this hypothetical nearprimary melt and primitive magmas from the Reykjanes Peninsula and NVZ imply that, even if they never reach the surface without modification, high-Mg\#, high- $\mathrm{Ca} / \mathrm{Na}$ and low-La/Yb melts are supplied to base of the EVZ as they are elsewhere in Iceland.

\section{Magma storage conditions of Hvítárvatn magmas}

Crystallisation of high-forsterite olivine $\left(\sim \mathrm{Fo}_{87}\right)$ and highanorthite plagioclase $\left(\sim \mathrm{An}_{92}\right)$ from compositionally variable but, on average, incompatible trace element-depleted melts, is the highest temperature magmatic process recorded directly in the Hvítárvatn tephra layer. High-Mg\# clinopyroxene $\left(\mathrm{Mg}_{\mathrm{cpx}} \sim 87\right)$ probably joined the liquidus at $\mathrm{Mg \#}_{\text {melt }} \sim 65$. Disequilibrium between primitive macrocrysts and both evolved macrocrysts $\left(\mathrm{An}_{60}-\mathrm{An}_{68}\right.$, $\left.\mathrm{Mg} \#_{\mathrm{cpx}}=71-78, \mathrm{Fo}_{70}-\mathrm{Fo}_{76}\right)$ and the matrix glass indicates that a low-La/ $\mathrm{Yb}$ cargo of primitive macrocrysts was mixed into a high-La/ $\mathrm{Yb}$, evolved carrier liquid shortly before eruption (c.f. Neave et al. 2014b). There is no petrological record of high- $\mathrm{La} / \mathrm{Yb}$ primitive melts contributing to the liquids that ultimately formed the matrix glass. High-anorthite plagioclase and high-Mg\# clinopyroxene macrocrysts only record the evolution of low-La/Yb melts, indicating that the evolved carrier liquid was aphyric at the time of mixing. Within this petrogenetic framework, there are two key questions that can be interrogated using thermobarometry: first, under what conditions did the evolved assemblage grow and equilibrate with the matrix glass and second, under what conditions did the primitive assemblage form?

\section{Thermal evolution of Hvitárvatn magmas}

Matrix glass and plagioclase-hosted melt inclusion temperatures calculated using Eq. 14 of Putirka (2008), a melt composition thermometer (standard error of estimate $\left.(\mathrm{SEE})= \pm 60{ }^{\circ} \mathrm{C}\right)$, are shown in Fig. 11. Matrix glass and evolved melt inclusion compositions record temperatures of $\sim 1140{ }^{\circ} \mathrm{C}$, whereas primitive plagioclase-hosted melt inclusion compositions mainly record temperatures within the range $1240-1300{ }^{\circ} \mathrm{C}$ (Fig. 11).

In $\mathrm{H}_{2} \mathrm{O}$-poor systems, temperatures calculated using olivine-melt equilibria are more precise than temperatures calculated from melt composition alone (Ford et al. 1983; Beattie 1993; Putirka 2008). Olivine-melt temperatures were calculated with Eq. 22 of Putirka (2008) $\left(\mathrm{SEE}= \pm 27^{\circ} \mathrm{C}\right)$ using plagioclase-hosted melt inclusion and matrix glass compositions that, according to Herzberg and O'Hara (2002), return $K_{\mathrm{d} \mathrm{Fe}-\mathrm{Mg}}^{\text {ol-liq }}$ values within $10 \%$ of equilibrium. Olivine-melt temperatures are consistent with melt-only temperatures (Fig. 11): $\sim \mathrm{Fo}_{85}$ olivines in
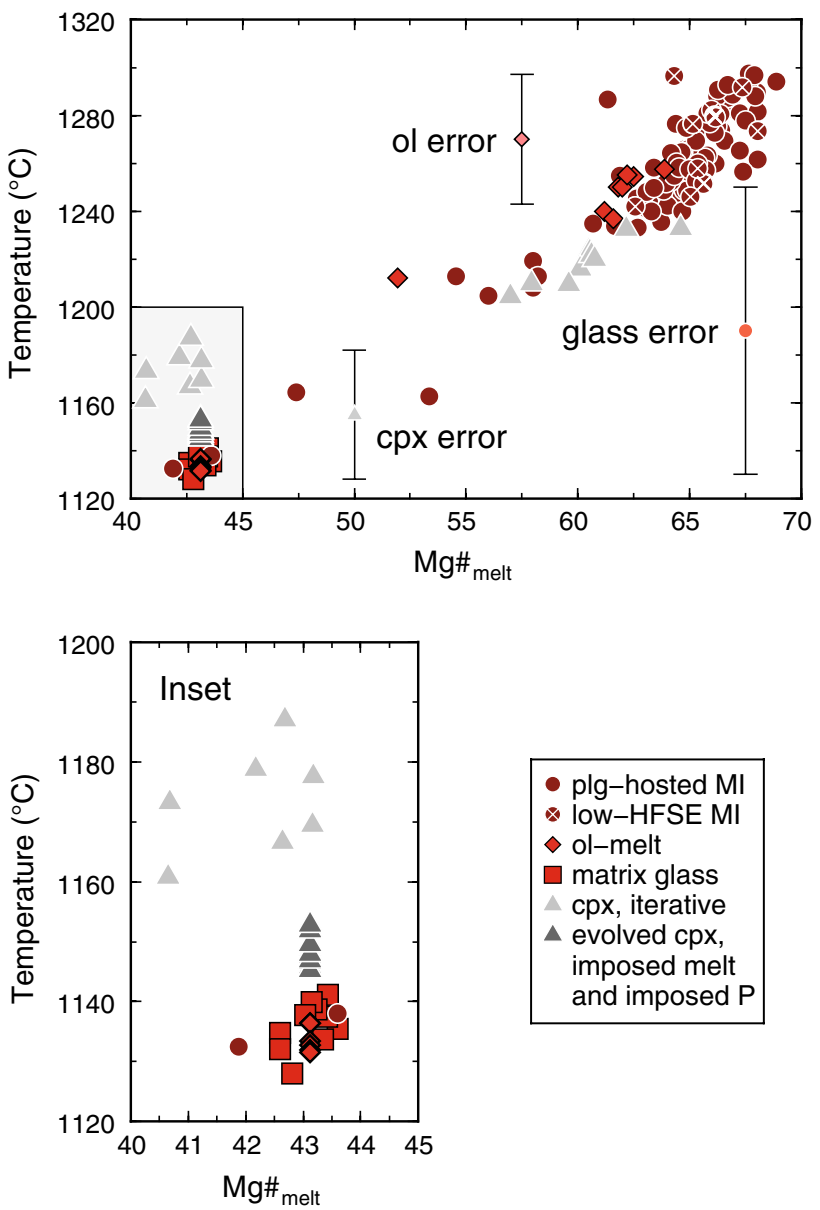

Fig. 11 Plot summarising the thermal evolution of melt inclusions, clinopyroxenes and the matrix glass in the Hvítárvatn tephra layer. The grey region of the upper plot shows the area enlarged for clarity in the lower plot. Melt inclusion and matrix glass temperatures were calculated using Eq. 15 from Putirka (2008). Olivine-melt temperatures were calculated using Eq. 22 from Putirka (2008) and plagioclase-hosted melt inclusion compositions that have $K_{d \text { Fe-Mg }}^{\text {olliq }}$ values within $10 \%$ of equilibrium according to Herzberg and O'Hara (2002). Clinopyroxene-melt equilibrium temperatures were calculated in two ways using the model of Putirka et al. (1996). First, equilibrium temperatures and pressures were calculated iteratively for each clinopyroxene using melts following the method of Neave et al. (2013) (pale grey triangles). Compared with melt and olivinemelt thermometers, these iterative calculations return high temperatures for evolved macrocrysts. Temperatures were also calculated for evolved clinopyroxenes in equilibrium with the matrix glass by assuming a pressure of 1 kbar (Fig. 12a). Calculations with this assumed pressure return similar temperatures to melt and olivinemelt thermometers (dark grey triangles). Standard errors of estimate are shown

equilibrium with $\mathrm{Mg} \#_{\text {melt }}=62$ record $\sim 1250{ }^{\circ} \mathrm{C}$ and $\sim \mathrm{Fo}_{72}$ olivines in equilibrium with $\mathrm{Mg \#}{ }_{\text {melt }}=43$ record $\sim 1140{ }^{\circ} \mathrm{C}$.

Two approaches were used to estimate temperatures using clinopyroxene-melt equilibria (Fig. 11). Following the method of Neave et al. (2013), temperatures and pressures were first calculated iteratively using equilibrium 
melt compositions selected from a database of Icelandic melt compositions (Shorttle and Maclennan 2011). Temperatures and pressures were estimated using the Jd-DiHd thermobarometer of Putirka et al. (1996) (SEE $= \pm 46{ }^{\circ} \mathrm{C}$ ) because it is calibrated specifically for $\mathrm{H}_{2} \mathrm{O}$-poor, mafic compositions. High-Mg\# clinopyroxene macrocrysts return temperatures of $1200-1240{ }^{\circ} \mathrm{C}$, consistent with estimates from melt inclusions and olivine macrocrysts. However, low-Mg\# clinopyroxene macrocrysts return temperatures of $1160-1190{ }^{\circ} \mathrm{C}$ that are substantially higher than those obtained for the evolved assemblage using other thermometers $\left(\sim 1140{ }^{\circ} \mathrm{C}\right)$. This overestimation results primarily from the model's convergence to overly high pressures (see below). In the second approach, clinopyroxenes in $\mathrm{Fe}-$ $\mathrm{Mg}$ equilibrium with the matrix glass return temperatures of $\sim 1150{ }^{\circ} \mathrm{C}$ when an equilibration pressure of $1 \mathrm{kbar}$ is assumed (see below).

Numerous thermometers thus indicate that high-anorthite plagioclase-hosted melt inclusions and high-forsterite olivine macrocrysts were derived from high-temperature, near-primary melts $\left(\geq 1240{ }^{\circ} \mathrm{C}\right)$. High-Mg\# clinopyroxene macrocryst temperatures are consistent with crystallisation alongside primitive olivine and plagioclase. Pre-eruptive temperatures of $\sim 1140{ }^{\circ} \mathrm{C}$ recorded by the evolved assemblage are consistent with those calculated for the compositionally similar AD 1783-1784 Laki eruption (Guilbaud et al. 2007; Neave et al. 2013).

\section{Magma storage depths and barometric inconsistencies}

Melt inclusion $\mathrm{CO}_{2}$ contents were used to calculate entrapment pressures with the $\Pi^{*}$ parameter model of Shishkina et al. (2014) developed from the $\Pi$ parameter model of Dixon (1997) with relative errors of $<20 \%$ based on uncertainties in model fits (Shishkina et al. 2014). Estimating entrapment pressures from melt volatile contents assumes that melts were fluid-saturated at the time of inclusion formation (Moore 2008). Whilst this assumption may not be valid in all circumstances (e.g. Saal et al. 2002), the low $\mathrm{CO}_{2} / \mathrm{Nb}$ content of HFSE-undepleted primitive melt inclusions from Hvítárvatn (mean $\mathrm{CO}_{2} / \mathrm{Nb}=159 \pm 74(1 \sigma)$ ) indicates that trapped melts achieved $\mathrm{CO}_{2}$ saturation before eruption: prior to volatile exsolution, Icelandic primary melt $\mathrm{CO}_{2} / \mathrm{Nb}$ contents are likely to be $\geq 300$ (Hauri et al. 2002; Hartley et al. 2014; Neave et al. 2014a). Evolved macrocryst-hosted melt inclusions record entrapment pressures of 0.7-1.5 kbar (Fig. 12). Most primitive melt inclusions have apparent entrapment pressures of 0.5-2.0 kbar, with a mean of $1.4 \mathrm{kbar}$. Eight inclusions record notably higher pressures of 2.0-5.2 kbar (Fig. 12).

As described above, clinopyroxene-melt pressures were calculated using the method of Neave et al. (2013) and the model of Putirka et al. (1996) (SEE $= \pm 1.4$ kbar).
Calculations performed on high-Al zones of low-Mg\# clinopyroxenes return pressures of 4.2-6.4 kbar, with a mean of 5.3 kbar. Calculations performed on high-Mg\# clinopyroxenes return higher pressures of 5.5-7.5 kbar, with a mean of $6.4 \mathrm{kbar}$ (Fig. 12a). Pressures calculated using clinopyroxene-melt equilibria are thus up to $\sim 5 \mathrm{kbar}$ higher than apparent melt inclusion entrapment pressures from the same macrocryst assemblage. In order to evaluate the depth at which magmas feeding the Hvítárvatn tephra eruption were stored and processed satisfactorily, this discrepancy needs to be resolved.

The pressure of last mineral-melt equilibration of threephase-saturated basalts can be estimated with an approximate uncertainty of $1 \mathrm{kbar}$ using the location of the olivine-plagioclase-augite-melt (OPAM) boundary (Yang et al. 1996). OPAM boundary locations for matrix glass compositions indicate that they last equilibrated with their crystal load at $1 \pm 1 \mathrm{kbar}$ (Fig. 12a), consistent with the $0.7-1.5$ kbar pressure recorded by the volatile content of the evolved melt inclusions. The difference between clinopyroxene-melt and melt inclusion/OPAM pressure estimates is beyond quoted model uncertainties, suggesting that clinopyroxene-melt pressures are incorrect.

If clinopyroxene-melt pressures are recalculated using an assumed temperature of $1140{ }^{\circ} \mathrm{C}$, pressures drop from 4.2-6.4 kbar to 3.6-4.1 kbar, which are still much greater than the $0.7-1.5$ kbar pressures recorded by evolved melt inclusions. However, Putirka (2008) noted that the model of Putirka et al. (1996) generally returns pressures that are 2-3 kbar too high for most $1 \mathrm{~atm}$ experiments. Whilst Putirka (2008) attributed this offset to $\mathrm{Na}$ volatilisation in furnace experiments (e.g. Tormey et al. 1987), the offset is still present when the thermobarometer is applied to clinopyroxene-melt pairs from experiments carried out at 1-7 kbar (Fig. 12b; Grove et al. 1992; Feig et al. 2006; Villiger et al. 2007; Feig et al. 2010). Nevertheless, if a pressure-dependent correction factor is applied to equilibrium low-Mg\# clinopyroxene-matrix glass pairs a posteriori (see regression in Fig. 12b), then the pressure range drops from 3.6-4.1 kbar to 0.0-0.7 kbar (Fig. 12a).

Assuming negligible ice cover and an average crustal density of $2700 \mathrm{~kg} \cdot \mathrm{m}^{-3}$, a pressure of $\sim 0.7 \mathrm{kbar}$ corresponds to a depth of $\sim 2.6 \mathrm{~km}$. However, we do not interpret this as a depth of long-term storage for the following reasons: first, the volume of each eruption in the $10 \mathrm{ka}$ Grímsvötn tephra series $\left(>1-30 \mathrm{~km}^{3}\right.$; Thordarson 2014) is at least comparable with that of the currently active shallow melt lens $\left(\sim 10 \mathrm{~km}^{3}\right.$; Alfaro et al. 2007). Assuming that Grímsvötn's subsurface architecture has not changed substantially over the past $\sim 10 \mathrm{ka}$, this comparison indicates that recharge from depth must have been efficient and continuous in order to avoid magma exhaustion on both intra- and inter-eruption timescales. Second, evolved 


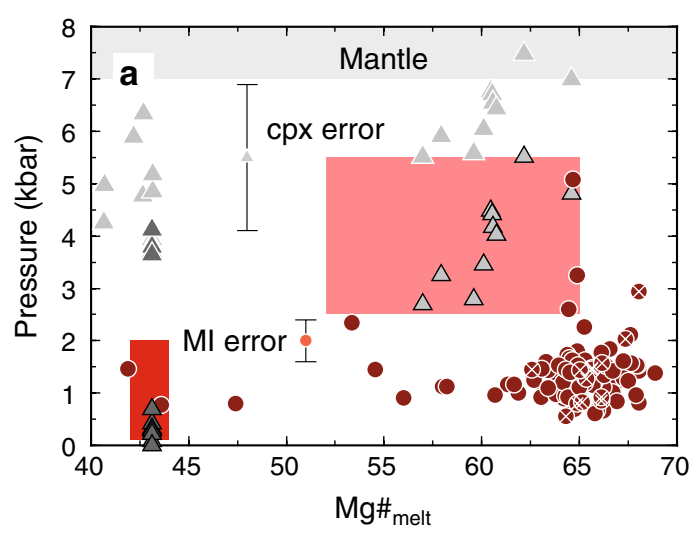

\begin{tabular}{|l}
\hline plg-hosted MI \\
$\otimes$ low-HFSE MI \\
$\diamond$ ol-hosted MI \\
matrix glasses \\
Mg\# ${ }_{\text {melt }}<65 \mathrm{Ml}$ \\
cpx, iterative P-T \\
$\triangle$ primtive cpx, iterative P-T \\
and corrected \\
$\Delta$ evolved cpx, imposed melt \\
and imposed T \\
$\Delta$ evolved cpx, imposed melt, \\
imposed T and corrected
\end{tabular}

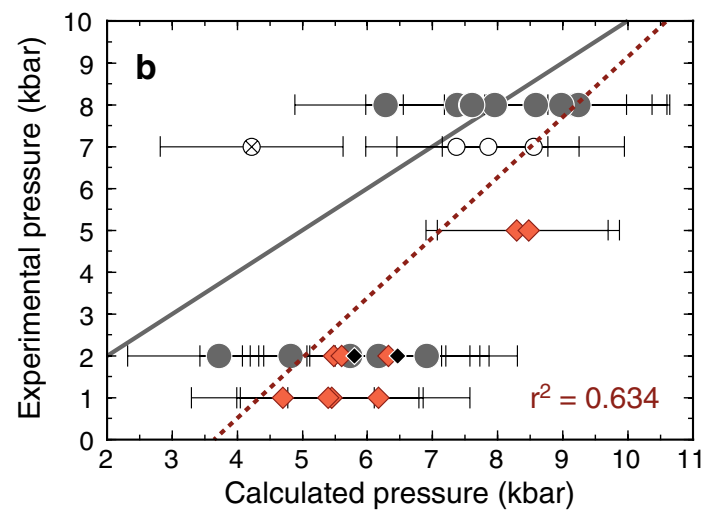

\begin{tabular}{|l|}
\hline Grove et al. (1992) \\
$\diamond$ Feig et al. (2006) \\
$\circ$ Villiger et al. (2007) \\
- Feig et al. (2010) \\
- one-to-one line \\
-. regression through \\
$\quad$ experimental data
\end{tabular}

Fig. 12 a Plot summarising the results of barometric calculations carried out on different components of the Hvítárvatn tephra layer. Melt inclusion entrapment pressures were calculated using the $\mathrm{CO}_{2}$ solubility model of Shishkina et al. (2014) and are shown as dark red circles. The $<20 \%$ error in melt inclusion entrapment pressures is based on the model's ability to fit experimental data (Shishkina et al. 2014). Equilibration pressures of three-phase saturated matrix glass compositions and $\mathrm{Mg} \#_{\text {melt }}<65$ melt inclusions were calculated using the olivine-plagioclase-augite-melt (OPAM) boundary barometer of Yang et al. (1996) and are shown as red and pale red boxes. Clinopyroxene-melt equilibrium pressures were calculated iteratively for all clinopyroxene analyses using the model of Putirka et al. (1996) and melts selected from a large database of Iceland melt compositions following the method of Neave et al. (2013) (pale grey triangles). Equilibrium pressures were also calculated for clinopyroxene macro-

macrocrysts textures-skeletal plagioclase rims (Fig. 2a) and clinopyroxene sector zoning (Fig. 2c) —are consistent with rapid crystallisation imminently before eruption. We therefore suggest that the evolved assemblage grew within a 0.0-1.5 kbar pressure interval following the mixing of primitive macrocrysts into an evolved, aphyric melt that differentiated deeper in the plumbing system (Neave et al. 2014b). Although this crystallisation may have taken place as magma stalled in ephemeral, small reservoirs whilst en route to the surface, it may also have taken place in transit.

Reconciling differences between primitive melt inclusion entrapment pressures and high-Mg\# clinopyroxene-melt pressures are more difficult. Applying a correction to high-Mg\# clinopyroxene-melt calculations yields crysts in equilibrium with the matrix glass using an imposed temperature of $1140{ }^{\circ} \mathrm{C}$ (dark grey triangles). A correction accounting for the systematic overestimation of pressure in experimental clinopyroxenemelt pairs was applied to both iteratively calculated primitive clinopyroxene pressures and imposed temperature evolved clinopyroxene pressures (pale and dark grey triangles with black outlines, respectively). The standard error of estimate for the Putirka et al. (1996) model is shown. b Plot comparing calculated and observed pressures for equilibrium clinopyroxene-melt pairs from experiments carried out in the pressure range 1-8 kbar. Experimental data were collated from Grove et al. (1992), Feig et al. (2006, 2010) and Villiger et al. (2007) and are not used in the calibration of the Putirka et al. (1996) model. Corrected clinopyroxene pressures shown in (a) were calculated using the regression line shown as a dotted line. The crossed data point was excluded from the regression

mid-crustal pressures of 2.5-5.5 kbar (Fig. 12a). However, given the significant uncertainties in the correction factor, clinopyroxene-melt pressures alone cannot be considered reliable. Through careful application of the OPAM barometer to melt inclusion compositions that were three-phase saturated at the time of entrapment, it is possible to place additional constraints on magma storage depths. Low$\mathrm{Mg \#}$ primitive inclusions $\left(\mathrm{Mg \#}_{\text {melt }}<65\right)$ return pressures of $4 \pm 1.5 \mathrm{kbar}$ which are consistent with corrected clinopyroxene-melt pressures (Fig. 12a) and the appearance of clinopyroxene on the liquidus after plagioclase (Presnall et al. 1978; Grove et al. 1992; Villiger et al. 2007).

The persistent discrepancy between melt inclusion entrapment pressures and clinopyroxene-melt pressures 
following the validation of corrected clinopyroxene-melt pressures with the OPAM barometer thus calls the validity of primitive melt inclusion entrapment pressures into question. Considering the convergence of mineral-melt equilibrium and melt composition barometers on $4 \pm 1.5 \mathrm{kbar}$, we suggest that most melt inclusion entrapment pressures no longer record the pressure of initial entrapment. Whilst a few high- $\mathrm{CO}_{2}$ inclusions (800-2100 ppm) may preserve true entrapment pressures of up to $5.2 \mathrm{kbar}$, we suggest that the mean entrapment pressure of $1.4 \mathrm{kbar}$ records pre-eruptive $\mathrm{CO}_{2}$ loss within the shallow plumbing system, possibly during formation of the evolved assemblage.

Whilst a number of studies have investigated the postentrapment behaviour of volatiles in olivine-hosted melt inclusions (e.g. Qin et al. 1992; Portnyagin et al. 2008; Bucholz et al. 2013; Hartley et al. 2015), volatile behaviour in plagioclase-hosted melt inclusions is less well understood. Whilst the high $\mathrm{H}_{2} \mathrm{O}$ content of melt inclusions precludes $\mathrm{CO}_{2}$ loss during the final stages of eruption, it is not currently possible to evaluate how $\mathrm{CO}_{2}$ may be transferred between inclusions and the external melt through plagioclase hosts, though diffusion along lattice defects and cleavage planes is likely to play a role (Viti and Frezzotti 2001; Kress and Ghiorso 2004). Nevertheless, once experimentally quantified, volatile exchange through plagioclase macrocrysts has the chronometric potential to reveal rates of immediately pre-eruptive processes.

Although interpreting the raw results of our barometric calculations at face value leads to barometric estimates that span the entire Icelandic crust for a single equilibrium assemblage (Darbyshire et al. 2000), re-assessing the reliability of pressure estimates on a barometer-by-barometer basis enables an internally consist model of magma storage to be developed. Multiple barometers indicate that the primitive macrocryst assemblage formed in the mid-crust at $4 \pm 1.5 \mathrm{kbar}(13.6 \pm 5.1 \mathrm{~km})$, whereas the evolved assemblage grew within the shallow crust at $0.0-1.5 \mathrm{kbar}$ $(0-5.2 \mathrm{~km})$. Mid-crustal pressures are consistent with the depths of recent seismogenic magmatism in Iceland (Sigmundsson et al. 2010; Tarasewicz et al. 2014; Guðmundsson et al. 2014), as well as with the depth at which ground deformation data suggest a deep reservoir may currently exist under Grímsvötn (Reverso et al. 2014). Uncertainties nevertheless remain in the calibration of clinopyroxene-melt equilibrium and the geological significance of the shallow entrapment pressures recorded by most plagioclase-hosted melt inclusions. In order to resolve the diverse pressure estimates obtained from different components of the Hvitárvatn tephra layer, further phase equilibria experiments within the crucial 1-7 kbar pressure interval are required to refine thermobarometric calibrations. The improvement of barometer calibrations is vital if petrological data are to be used to inform ongoing volcano monitoring strategies.

\section{Conclusions}

Matrix glass compositions from the $\sim 10 \mathrm{ka}$ Grímsvötn tephra series (i.e. Saksunarvatn ash) at Hvítárvatn, central Iceland are consistent with an affinity with the Grímsvötn volcanic system. Macrocrysts can be divided into two populations based on their degree of evolution and incompatible trace element enrichment. The evolved assemblage contains low-anorthite plagioclase, low-Mg\# clinopyroxene, low-forsterite olivine macrocrysts and macrocryst rims that are close to being in equilibrium with the matrix glass. The primitive assemblage contains high-anorthite plagioclase, low-Mg\# clinopyroxene and low-forsterite olivine macrocryst cores that are in equilibrium with primitive, incompatible trace element-depleted melt inclusions. Trace element disequilibrium between primitive and evolved assemblages probably resulted from the disaggregation of primitive crystal mushes into evolved and aphyric melts shortly before eruption. Although a subset of primitive plagioclase-hosted melt inclusions exhibits HFSE depletions that reflect their formation by macrocryst dissolution within plagioclase-undersaturated melts, post-entrapment modification of major and trace element compositions was otherwise minimal. Primitive plagioclase-hosted inclusions record the supply of compositionally diverse mantle melts to the base of the Grímsvötn plumbing system that subsequently underwent fractional crystallisation dominated by the removal of an initially troctolitic then gabbroic assemblage. Primitive eruptives from the NVZ and Reykjanes Peninsula provide the closest analogues to a hypothetical near-primary melt composition for the Hvítárvatn primitive assemblage.

Final pre-eruptive mineral-melt equilibration of evolved assemblage occurred at $1140{ }^{\circ} \mathrm{C}$ and $0.0-1.5$ kbar. The large volume of the tephra-forming eruption and the presence of textures consistent with rapid crystallisation within the evolved macrocrysts are inconsistent with $0.0-1.5 \mathrm{kbar}$ representing a depth of long-term magma storage. Numerous thermometers indicate that primitive macrocrysts and melt inclusions they contain formed at much higher temperatures than the evolved assemblage: $1240-1300{ }^{\circ} \mathrm{C}$. Although most primitive melt inclusions record apparent entrapment pressures of $1.4 \mathrm{kbar}$ based on their $\mathrm{CO}_{2}$ content, other barometers consistently return mid-crustal pressures of $4 \pm 1.5$ kbar when evaluated critically. Barometric convergence on mid-crustal pressures indicates that most primitive melt inclusions lost $\mathrm{CO}_{2}$ during transport through the shallow crust. Assessing the accuracy and precision of mid-crustal clinopyroxene-melt pressure 
estimates is nevertheless impaired by incomplete calibration of barometers under the conditions relevant to magmatic processes beneath Iceland. In order to improve the fidelity of petrological estimates of magma storage depths, continued exploration of basalt phase equilibria in the crucial 1-7 kbar pressure interval is required.

Acknowledgments D.A.N. was supported by a Natural Environment Research Council studentship (NE/1528277/1) at the start of this project. SIMS analyses were supported by Natural Environment Research Council Ion Microprobe Facility award (IMF508/1013). We would like to thank Robin Clarke and Iris Buisman for their help with sample preparation and EPMA at the University of Cambridge. We also thank Richard Hinton and all the staff at the Ion Microprobe Facility at University of Edinburgh for their assistance with SIMS analyses. We are very grateful to two anonymous reviewers for their detailed and highly constructive reviews as well as to Othmar Müntener for his efficient editorial handling.

Open Access This article is distributed under the terms of the Creative Commons Attribution 4.0 International License (http://creativecommons.org/licenses/by/4.0/), which permits unrestricted use, distribution, and reproduction in any medium, provided you give appropriate credit to the original author(s) and the source, provide a link to the Creative Commons license, and indicate if changes were made.

\section{References}

Aigner-Torres M, Blundy JD, Ulmer P, Pettke T (2007) Laser ablation ICPMS study of trace element partitioning between plagioclase and basaltic melts: an experimental approach. Contrib Mineral Petrol 153:647-667. doi:10.1007/s00410-006-0168-2

Alfaro R, Brandsdóttir B, Rowlands DP et al (2007) Structure of the Grímsvötn central volcano under the Vatnajökull icecap, Iceland. Geophys J Int 168:863-876. doi:10.1111/j.1365-246X.2006.03238.x

Anderson AT, Brown GG (1993) $\mathrm{CO}_{2}$ contents and formation pressures of some Kilauean melt inclusions. Am Mineral 78:794-803

Arevalo R, McDonough WF (2010) Chemical variations and regional diversity observed in MORB. Chem Geol 271:70-85. doi:10.1016/j.chemgeo.2009.12.013

Beattie P (1993) Olivine-melt and orthopyroxene-melt equilibria. Contrib Mineral Petrol 115:103-111

Beattie P (1994) Systematics and energetics of trace-element partitioning between olivine and silicate melts: implications for the nature of mineral/melt partitioning. Chem Geol 117:57-71

Bédard JH (2006) Trace element partitioning in plagioclase feldspar. Geochim Cosmochim Acta 70:3717-3742. doi:10.1016/j. gca.2006.05.003

Björck S, Ingólfsson Ó, Haflidason H et al (1992) Lake Torfadalsvatn: a high resolution record of the North Atlantic ash zone I and the last glacial-interglacial environmental changes in Iceland. Boreas 21:15-22. doi:10.1111/j.1502-3885.1992. tb00009.x

Blundy JD, Wood BJ (1991) Crystal-chemical controls on the partitioning of $\mathrm{Sr}$ and $\mathrm{Ba}$ between plagioclase feldspar, silicate melts, and hydrothermal solutions. Geochim Cosmochim Acta 55:193-209. doi:10.1016/0016-7037(91)90411-W

Blundy JD, Wood BJ (1994) Prediction of crystal melt partition coefficients from elastic moduli. Nature 372:452-454
Bramham-Law CWF, Theuerkauf M, Lane CS, Mangerud J (2013) New findings regarding the Saksunarvatn Ash in Germany. J Quat Sci 28:248-257. doi:10.1002/jqs.2615

Breddam K (2002) Kistufell: primitive melt from the Iceland Mantle Plume. J Petrol 43:345-373. doi:10.1093/petrology/43.2.345

Brice JC (1975) Some thermodynamic aspects of the growth of strained crystals. J Cryst Growth 28:249-253

Bucholz CE, Gaetani GA, Behn MD, Shimizu N (2013) Post-entrapment modification of volatiles and oxygen fugacity in olivinehosted melt inclusions. Earth Planet Sci Lett 374:145-155. doi:10.1016/j.epsl.2013.05.033

Cottrell E, Spiegelman M, Langmuir CH (2002) Consequences of diffusive reequilibration for the interpretation of melt inclusions. Geochem Geophys Geosyst 3:1-26. doi:10.1029/200 $1 \mathrm{GC} 000205$

Danyushevsky LV, Plechov P (2011) Petrolog 3: integrated software for modelling crystallization processes. Geochem Geophys Geosyst 12:Q07021. doi:10.1029/2011GC003516

Danyushevsky LV, Della-Pasqua FN, Sokolov S (2000) Re-equilibration of melt inclusions trapped by magnesian olivine phenocrysts from subduction-related magmas: petrological implications. Contrib Mineral Petrol 138:68-83

Danyushevsky LV, McNeill AW, Sobolev AV (2002) Experimental and petrological studies of melt inclusions in phenocrysts from mantle-derived magmas: an overview of techniques, advantages and complications. Chem Geol 183:5-24. doi:10.1016/ S0009-2541(01)00369-2

Danyushevsky LV, Perfit MR, Eggins SM, Falloon TJ (2003) Crustal origin for coupled "ultra-depleted" and "plagioclase" signatures in MORB olivine-hosted melt inclusions: evidence from the Siqueiros Transform Fault, East Pacific Rise. Contrib Mineral Petrol 144:619-637. doi:10.1007/s00410-002-0420-3

Darbyshire FA, White RS, Priestley KF (2000) Structure of the crust and uppermost mantle of Iceland from a combined seismic and gravity study. Earth Planet Sci Lett 181:409-428. doi:10.1016/ S0012-821X(00)00206-5

Dixon JE (1997) Degassing of alkalic basalts. Am Mineral 82:368-378

Dixon JE, Stolper EM, Holloway JR (1995) An experimental study of water and carbon dioxide solubilities in mid-ocean ridge basaltic liquids. Part I: calibration and solubility models. J Petrol 36:1607-1631

Duncan R, Green D (1987) The genesis of refractory melts in the formation of oceanic crust. Contrib Mineral Petrol 96:326-342

Dungan MA, Rhodes JM (1978) Residual glasses and melt inclusions in basalts from DSDP Legs 45 and 46: evidence for magma mixing. Contrib Mineral Petrol 431:417-431

Elliott TR, Hawkesworth CJ, Grönvold K (1991) Dynamic melting of the Iceland plume. Nature 351:201-206

Feig ST, Koepke J, Snow JE (2006) Effect of water on tholeiitic basalt phase equilibria: an experimental study under oxidizing conditions. Contrib Mineral Petrol 152:611-638. doi:10.1007/ s00410-006-0123-2

Feig ST, Koepke J, Snow JE (2010) Effect of oxygen fugacity and water on phase equilibria of a hydrous tholeiitic basalt. Contrib Mineral Petrol 160:551-568. doi:10.1007/s00410-010-0493-3

Ford CE, Russell DG, Craven JA, Fisk MR (1983) Olivine-liquid equilibria: temperature, pressure and composition dependence of the crystal/liquid cation partition coefficients for $\mathrm{Mg}, \mathrm{Fe}^{2+}$, $\mathrm{Ca}$ and Mn. J Petrol 24:256-265

Gaetani GA, Watson EB (2000) Open system behavior of olivinehosted melt inclusions. Earth Planet Sci Lett 183:27-41. doi:10.1016/S0012-821X(00)00260-0

Ghiorso MS, Hirschmann MM, Reiners PW, Kress VC (2002) The pMELTS: a revision of MELTS for improved calculation of phase relations and major element partitioning related to partial 
melting of the mantle to $3 \mathrm{GPa}$. Geochem Geophys Geosyst 3:1030. doi:10.1029/2001GC000217

Grönvold K, Óskarsson N, Johnsen S et al (1995) Ash layers from Iceland in the Greenland GRIP ice core correlated with oceanic and land sediments. Earth Planet Sci Lett 35:149-155

Grove TL, Kinzler RJ, Bryan WB (1992) Fractionation of midocean ridge basalt (MORB). Geophys Monogr Geophys Union $71: 281-310$

Guðmundsson Á, Lecoeur N, Mohajeri N, Thordarson T (2014) Dike emplacement at Bardarbunga, Iceland, induces unusual stress changes, caldera deformation, and earthquakes. Bull Volcanol 76:869. doi:10.1007/s00445-014-0869-8

Guilbaud M-N, Blake S, Thordarson T, Self S (2007) Role of Syneruptive cooling and degassing on textures of lavas from the AD 1783-1784 Laki eruption, South Iceland. J Petrol 48:12651294. doi:10.1093/petrology/egm017

Gurenko AA, Chaussidon M (1995) Enriched and depleted primitive melts included in olivine from Icelandic tholeiites-origin by melting of a single mantle column. Geochim Cosmochim Acta 59:2905-2917

Gurenko AA, Sobolev AV (2006) Crust-primitive magma interaction beneath neovolcanic rift zone of Iceland recorded in gabbro xenoliths from Midfell, SW Iceland. Contrib Mineral Petrol 151:495-520. doi:10.1007/s00410-006-0079-2

Haflidason H, Eiriksson J, Van Kreveld S (2000) The tephrochronology of Iceland and the North Atlantic region during the middle and Late Quaternary: a review. J Quat Sci 15:3-22. doi:10.1002/ (SICI)1099-1417(200001)15:1<3:AID-JQS530>3.0.CO;2-W

Halldórsson SA, Óskarsson N, Grönvold K et al (2008) Isotopic-heterogeneity of the Thjorsa lava-implications for mantle sources and crustal processes within the Eastern Rift Zone, Iceland. Chem Geol 255:305-316. doi:10.1016/j.chemgeo.2008.06.050

Hansen H, Grönvold K (2000) Plagioclase ultraphyric basalts in Iceland: the mush of the rift. J Volcanol Geotherm Res 98:1-32. doi:10.1016/S0377-0273(99)00189-4

Hart SR, Dunn T (1993) Experimental cpx/melt partitioning of 24 trace elements. Contrib Mineral Petrol 113:1-8. doi:10.1007/ BF00320827

Hartley ME, Maclennan J, Edmonds M, Thordarson T (2014) Reconstructing the deep $\mathrm{CO}_{2}$ degassing behaviour of large basaltic fissure eruptions. Earth Planet Sci Lett 393:120-131. doi:10.1016/j.eps1.2014.02.031

Hartley ME, Neave DA, Maclennan J et al (2015) Diffusive overhydration of olivine-hosted melt inclusions. Earth Planet Sci Lett 425:168-178. doi:10.1016/j.epsl.2015.06.008

Hauri EH, Grönvold K, Óskarsson N, McKenzie D (2002) Abundance of carbon in the Icelandic mantle: constraints from melt inclusions. Am Geophys Union, Spring Meet, p V51D-03

Herzberg C, O'Hara MJ (2002) Plume-associated ultramafic magmas of Phanerozoic Age. J Petrol 43:1857-1883. doi:10.1093/ petrology/43.10.1857

Jakobsson SP (1979) Petrology of recent basalts of the Eastern Volcanic Zone, Iceland. Acta Nat Islandica 26:1-103

Jakobsson SP, Jónsson J, Shido F (1978) Petrology of the western Reykjanes peninsula, Iceland. J Petrol 19:669-705

Jennings A, Thordarson T, Zalzal K et al (2014) Holocene tephra from Iceland and Alaska in SE Greenland Shelf Sediments. Mar Tephrochronol. doi:10.1144/SP398.6

Jochum KP, Willbold M, Raczek I et al (2005) Chemical characterisation of the USGS reference glasses and BIR-1G Using EPMA, ID-TIMS, ID-ICP-MS and LA-ICP-MS. Geostand Geoanal Res 29:285-302

Jochum KP, Stoll B, Herwig K et al (2006) MPI-DING reference glasses for in situ microanalysis: new reference values for element concentrations and isotope ratios. Geochem Geophys Geosyst 7:Q02008
Jochum KP, Weis U, Stoll B et al (2011) Determination of reference values for NIST SRM 610-617 glasses following ISO guidelines. Geostand Geoanal Res 35:397-429. doi:10.1111/j.1751-908X.2011.00120.x

Jóhannsdóttir GE (2007) Mid Holocene to late glacial tephrochronology in West Iceland as revealed in three lacustrine environments. Masters Thesis, University of Iceland

Jóhansen J (1975) Pollen diagrams from the Shetland and Faroe Islands. New Phytol 75:369-387

Jóhansen J (1985) Studies in the vegatation history of the Faroe and Shetland Islands. Føroya Fróðskaparfelag, Tórshavn

Jóhannsdóttir GE, Thordarson T, Geirsdóttir A, Larsen G (2005) The widespread $\sim 10$ ka Saksunarvatn Tephra : a product of three large basaltic Phreatoplinian eruptions? Geophys Res Abstr 7:05991

Jude-Eton TC, Thordarson T, Guðmundsson MT, Oddsson B (2012) Dynamics, stratigraphy and proximal dispersal of supraglacial tephra during the ice-confined 2004 eruption at Grímsvötn Volcano, Iceland. Bull Volcanol 74:1057-1082. doi:10.1007/ s00445-012-0583-3

Kilgour GN, Saunders KE, Blundy JD et al (2014) Timescales of magmatic processes at Ruapehu volcano from diffusion chronometry and their comparison to monitoring data. J Volcanol Geotherm Res 288:62-75. doi:10.1016/j. jvolgeores.2014.09.010

Kinzler RJ, Grove TL (1992) Primary magmas of mid-ocean ridge basalts 1. Experiments and methods. J Geophys Res Solid Earth 97:6885-6906

Kogiso T, Hirose K, Takahashi E (1998) Melting experiments on homogeneous mixtures of peridotite and basalt: application to the genesis of ocean island basalts. Earth Planet Sci Lett 162:45-61

Koornneef JM, Stracke A, Bourdon B et al (2012) Melting of a two-component source beneath Iceland. J Petrol 53:127-157. doi:10.1093/petrology/egr059

Kress VC, Ghiorso MS (2004) Thermodynamic modeling of postentrapment crystallization in igneous phases. J Volcanol Geotherm Res 137:247-260. doi:10.1016/j.jvolgeores.2004.05.012

Langmuir CH, Klein EM, Plank T (1992) Petrological systematics of mid-ocean ridge basalts: constraints on melt generation beneath ocean ridges. Mantle flow and melt generation at mid-ocean ridges, 71st edn. Geophys Monogr. American Geophysical Union, pp 183-280

Larsen G (1984) Recent volcanic history of the Veidivötn fissure swarm, southern Iceland - an approach to volcanic risk assessment. J Volcanol Geotherm Res 22:33-58

Larsen G (2005) Explosive volcanism in Iceland: three examples of hydromagmatic basaltic eruptions on long volcanic fissures within the past 1200 years. Geophys Res Abstr 7:10158

LaTourrette T, Wasserburg G, Fahey A (1996) Self diffusion of Mg, $\mathrm{Ca}, \mathrm{Ba}, \mathrm{Nd}, \mathrm{Yb}, \mathrm{Ti}, \mathrm{Zr}$, and $\mathrm{U}$ in haplobasaltic melt. Geochim Cosmochim Acta 60:1329-1340

Lawson I, Gathorne-Hardy F, Church M et al (2007) Environmental impacts of the Norse settlement: palaeoenvironmental data from Mývatnssveit, northern Iceland. Boreas 36:1-19. doi: $10.1080 / 03009480600827298$

Lofgren GE (1974) An experimental study of plagioclase morphology: isothermal crystallisation. Am J Sci 274:243-273

Lohne ØS, Mangerud J, Birks HH (2014) IntCal13 calibrated ages of the Vedde and Saksunarvatn ashes and the Younger Dryas boundaries from Kråkenes, western Norway. J Quat Sci 29:506-507. doi:10.1002/jqs.2722

Lowenstern J (1995) Applications of silicate-melt inclusions to the study of magmatic volatiles. In: Thompson JFH (ed) Magmas, fluids and ore deposits. Mineral Association Canada Short Course Series 23, pp 71-99 
Maclennan J (2008a) Lead isotope variability in olivine-hosted melt inclusions from Iceland. Geochim Cosmochim Acta 72:4159-4176

Maclennan J (2008b) Concurrent mixing and cooling of melts under Iceland. J Petrol 49:1931-1953. doi:10.1093/petrology/egn052

Maclennan J, McKenzie D, Grönvold K (2001) Plume-driven upwelling under central Iceland. Earth Planet Sci Lett 194:67-82

Maclennan J, McKenzie D, Hilton F et al (2003) Geochemical variability in a single flow from northern Iceland. J Geophys Res Solid Earth 108:1-21. doi:10.1029/2000JB000142

Mangerud J, Furnes H, Jóhansen J (1986) A 9000-year-old ash bed on the Faroe Islands. Quat Res 265:262-265

McKenzie D, O'Nions RK (1991) Partial melt distributions from inversion of rare earth element concentrations. J Petrol 32:1021

Merkt J, Müller H, Knabe W et al (1993) The early Holocene Saksunarvatn tephra found in lake sediments in NW Germany. Boreas 22:93-100

Métrich N, Wallace PJ (2008) Volatile abundances in basaltic magmas and their degassing paths tracked by melt inclusions. Rev Mineral Geochem 69:363-402. doi:10.2138/rmg.2008.69.10

Michael PJ, McDonough WF, Nielsen RL, Cornell WC (2002) Depleted melt inclusions in MORB plagioclase: messages from the mantle or mirages from the magma chamber? Chem Geol 183:43-61. doi:10.1016/S0009-2541(01)00371-0

Moore $\mathrm{G}$ (2008) Interpreting $\mathrm{H}_{2} \mathrm{O}$ and $\mathrm{CO}_{2}$ contents in melt inclusions: constraints from solubility experiments and modeling. Rev Mineral Geochem 69:333-362. doi:10.2138/rmg.2008.69.9

Moore JG, Calk LC (1991) Degassing and differentiation in subglacial volcanoes, Iceland. J Volcanol Geotherm Res 46:157-180. doi:10.1016/0377-0273(91)90081-A

Moore LR, Gazel E, Tuohy R et al (2015) Bubbles matter: an assessment of the contribution of vapor bubbles to melt inclusion volatile budgets. Am Mineral 100:806-823

Nakamura Y (1973) Origin of sector-zoning of igneous clinopyroxenes. Am Mineral 58:986-990

Nakamura M, Shimakita S (1998) Dissolution origin and synentrapment compositional change of melt inclusion in plagioclase. Earth Planet Sci Lett 161:119-133. doi:10.1016/ S0012-821X(98)001447

Namur O, Charlier B, Toplis M, Vander Auwera J (2011) Prediction of plagioclase-melt equilibria in anhydrous silicate melts at 1-atm. Contrib Mineral Petrol 163:133-150. doi:10.1007/ s00410-011-0662-z

Neave DA, Fabbro G, Herd RA et al (2012) Melting, differentiation and degassing at the Pantelleria Volcano, Italy. J Petrol 53:637663. doi:10.1093/petrology/egr074

Neave DA, Passmore E, Maclennan J et al (2013) Crystal-melt relationships and the record of deep mixing and crystallization in the AD 1783-84 Laki eruption, Iceland. J Petrol 54:1661-1690. doi:10.1093/petrology/egt027

Neave DA, Maclennan J, Edmonds M, Thordarson T (2014a) Melt mixing causes negative correlation of trace element enrichment and $\mathrm{CO}_{2}$ content prior to an Icelandic eruption. Earth Planet Sci Lett 400:272-283

Neave DA, Maclennan J, Hartley ME et al (2014b) Crystal storage and transfer in basaltic systems: the Skuggafjöll eruption, Iceland. J Petrol 55:2311-2356. doi:10.1093/petrology/egu058

Nielsen RL (1995) Local diversity of MORB parent magmas: evidence from melt inclusions in high - an feldspar from the Gorda Ridge. Contrib Mineral Petrol 122:34-50. doi:10.1180/ minmag.1994.58A.2.75

Nielsen RL (2011) The effects of re-homogenization on plagioclase hosted melt inclusions. Geochem Geophys Geosyst 12:Q0AC17. doi:10.1029/2011GC003822
Nimis P (1995) A clinopyroxene geobarometer for basaltic systems based on crystal-structure modeling. Contrib Mineral Petrol 121:115-125

Óladottir BA, Thordarson T, Larsen G, Sigmarsson O (2007) Survival of the Myrdalsjökull ice cap through the Holocene thermal maximum: evidence from sulphur contents in Katla tephra layers (Iceland) from the last 8400 years. Ann Glaciol 45:183-188

Óladóttir BA, Sigmarsson O, Larsen G, Thordarson T (2007) Katla volcano, Iceland: magma composition, dynamics and eruption frequency as recorded by Holocene tephra layers. Bull Volcanol 70:475-493. doi:10.1007/s00445-007-0150-5

Óskarsson N, Helgason Ö, Steinthórsson S (1994) Oxidation state of iron in mantle-derived magmas of the Icelandic rift zone. Hyperfine Interact 91:733-737. doi:10.1007/BF02064599

Panjasawatwong Y, Danyushevsky LV, Crawford AJ, Harris KL (1995) An experimental study of the effects of melt composition on plagioclase-melt equilibria at 5 and $10 \mathrm{kbar}$ : implications for the origin of magmatic high - an plagioclase. Contrib Mineral Petrol 118:420-432

Passmore E, Maclennan J, Fitton JG, Thordarson T (2012) Mush disaggregation in basaltic magma chambers: evidence from the $\mathrm{AD}$ 1783-84 Laki eruption. J Petrol 35:2593-2623

Portnyagin M, Almeev R, Matveev S, Holtz F (2008) Experimental evidence for rapid water exchange between melt inclusions in olivine and host magma. Earth Planet Sci Lett 272:541-552. doi:10.1016/j.epsl.2008.05.020

Presnall DC, Dixon SA, Dixon JR et al (1978) Liquidus phase relations on the join diopside-forsterite-anorthite from 1 atm to 20 kbar: their bearing on the generation and crystallization of basaltic magma. Contrib Mineral Petrol 220:203-220

Putirka KD (2008) Thermometers and barometers for volcanic systems. Rev Mineral Geochem 69:61-120

Putirka KD, Johnson M, Kinzler R et al (1996) Thermobarometry of mafic igneous rocks based on clinopyroxene-liquid equilibria, 0-30 kbar. Contrib Mineral Petrol 123:92-108. doi:10.1007/ s004100050145

Qin Z, Lu F, Anderson T Jr (1992) Diffusive reequilibration of melt and fluid inclusions. Am Mineral 77:565-576

Rasmussen SO, Andersen KK, Svensson AM et al (2006) A new Greenland ice core chronology for the last glacial termination. J Geophys Res 111:D06102. doi:10.1029/2005JD006079

Reverso T, Vandemeulebrouck J, Jouanne F et al (2014) A two-magma chamber model as a source of deformation at Grímsvötn Volcano, Iceland. J Geophys Res Solid Earth 119:4666-4683. doi:1 0.1002/2013JB010569

Roedder E (1979) Origin and significance of magmatic inclusions. Bull Minéral 102:487-510

Rubin KH, Sinton JM, Maclennan J, Hellebrand E (2009) Magmatic filtering of mantle compositions at mid-ocean-ridge volcanoes. Nat Geosci 2:321-328. doi:10.1038/ngeo504

Saal AE, Hauri EH, Langmuir CH, Perfit MR (2002) Vapour undersaturation in primitive mid-ocean-ridge basalt and the volatile content of Earth's upper mantle. Nature 419:451-455. doi:10.1038/ nature 01073

Saunders K, Blundy JD, Dohmen R, Cashman K (2012) Linking petrology and seismology at an active volcano. Science 336:1023-1027. doi:10.1126/science.1220066

Shishkina TA, Botcharnikov RE, Holtz F et al (2010) Solubility of $\mathrm{H}_{2} \mathrm{O}$ - and $\mathrm{CO}_{2}$-bearing fluids in tholeiitic basalts at pressures up to $500 \mathrm{MPa}$. Chem Geol 277:115-125. doi:10.1016/j. chemgeo.2010.07.014

Shishkina TA, Botcharnikov RE, Holtz F et al (2014) Compositional and pressure effects on the solubility of $\mathrm{H}_{2} \mathrm{O}$ and $\mathrm{CO}_{2}$ in mafic melts. Chem Geol 388:112-129. doi:10.1016/j.chemgeo.2014.09.001 
Shorttle O, Maclennan J (2011) Compositional trends of Icelandic basalts: implications for short-lengthscale lithological heterogeneity in mantle plumes. Geochem Geophys Geosyst 12:Q11008

Sigmarsson O, Karlsson H, Larsen G (2000) The 1996 and 1998 subglacial eruptions beneath the Vatnajökull ice sheet in Iceland: contrasting geochemical and geophysical inferences on magma migration. Bull Volcanol 61:468-476. doi:10.1007/PL00008912

Sigmarsson O, Haddadi B, Carn S et al (2013) The sulfur budget of the 2011 Grímsvötn eruption, Iceland. Geophys Res Lett 40:6095-6100

Sigmundsson F, Hreinsdóttir S, Hooper A et al (2010) Intrusion triggering of the 2010 Eyjafjallajökull explosive eruption. Nature 468:426-430. doi:10.1038/nature09558

Sigurgeirsson MÁ, Leósson MA (1993) Two early Holocene tephra layers in the Sogamyri peat deposit Reykjavik. Náttúrufræðingurinn 62:129-137

Sinton JM, Detrick RS (1992) Mid-ocean ridge magma chambers. J Geophys Res Solid Earth 97:197-216. doi:10.1029/91JB02508

Slater L, McKenzie D, Grönvold K, Shimizu N (2001) Melt generation and movement beneath Theistareykir, NE Iceland. J Petrol 42:321-354

Sobolev AV, Shimizu N (1993) Ultra-depleted primary melt included in an olivine from the Mid-Atlantic Ridge. Nature 363:151-154

Sours-Page R, Nielsen RL, Batiza R (2002) Melt inclusions as indicators of parental magma diversity on the northern East Pacific Rise. Chem Geol 183:237-261. doi:10.1016/ S0009-2541(01)00384-9

Steele-Macinnis MJ, Esposito R, Bodnar RJ (2011) Thermodynamic model for the effect of post-entrapment crystallization on the $\mathrm{H}_{2} \mathrm{O}-\mathrm{CO}_{2}$ systematics of vapor-saturated, silicate melt inclusions. J Petrol 52:2461-2482. doi:10.1093/petrology/egr052

Stracke A, Zindler A, Salters VJM et al (2003) Theistareykir revisited. Geochem Geophys Geosyst 4:8507

Streeter R, Dugmore A (2014) Late-Holocene land surface change in a coupled social-ecological system, southern Iceland: a crossscale tephrochronology approach. Quat Sci Rev 86:99-114. doi:10.1016/j.quascirev.2013.12.016

Tarasewicz J, White RS, Brandsdóttir B, Schoonman CM (2014) Seismogenic magma intrusion before the 2010 eruption of Eyjafjallajokull volcano, Iceland. Geophys J Int 198:906-921. doi:10.1093/gji/ggu169

Thirlwall MF, Gee MAM, Taylor RN, Murton BJ (2004) Mantle components in Iceland and adjacent ridges investigated using double-spike $\mathrm{Pb}$ isotope ratios. Geochim Cosmochim Acta 68:361-386

Thomson A, Maclennan J (2013) The distribution of olivine compositions in Icelandic basalts and picrites. J Petrol 54:745-768. doi:10.1093/petrology/egs083

Thordarson T (2014) The widespread $\sim 10$ ka Saksunarvatn tephra is not a product single eruption. Am Geophys Union, Fall Meet, p V24B-04
Thordarson T, Höskuldsson Á (2008) Postglacial volcanism in Iceland. Jökull 58:197-228

Thordarson T, Self S, Óskarsson N, Hulsebosch T (1996) Sulfur, chlorine, and fluorine degassing and atmospheric loading by the 1783-1784 AD Laki (Skaftár Fires) eruption in Iceland. Bull Volcanol 58:205-225. doi:10.1007/s004450050136

Thornalley DJR, McCave IN, Elderfield H (2011) Tephra in deglacial ocean sediments south of Iceland: stratigraphy, geochemistry and oceanic reservoir ages. J Quat Sci 26:190-198. doi: $10.1002 /$ jqs. 1442

Tormey DR, Grove TL, Bryan WB (1987) Experimental petrology of normal MORB near the Kane Fracture Zone: $20-25^{\circ} \mathrm{N}$, midAtlantic ridge. Contrib Mineral Petrol 96:121-139

Tuffen H, Owen J, Denton J (2010) Magma degassing during subglacial eruptions and its use to reconstruct palaeo-ice thicknesses. Earth Sci Rev 99:1-18. doi:10.1016/j.earscirev.2010.01.001

Villiger S, Ulmer P, Müntener O (2007) Equilibrium and fractional crystallization experiments at $0.7 \mathrm{GPa}$; the Effect of pressure on phase relations and liquid compositions of Tholeiitic magmas. $\mathbf{J}$ Petrol 48:159-184. doi:10.1093/petrology/eg1058

Viti C, Frezzotti ML (2001) Transmission electron microscopy applied to fluid inclusion investigations. Lithos 55:125-138. doi:10.1016/S0024-4937(00)00042-6

Waagstein R, Jóhansen J (1968) Tre vulkanske askelage fra Færø. Meddelelser fra Dansk Geol Foren 18:257-264

Wallace PJ, Kamenetsky VS, Cervantes P (2015) Melt inclusion $\mathrm{CO}_{2}$ contents, pressures of olivine crystallization, and the problem of shrinkage bubbles. Am Mineral 100:787-794

Walter MJ (1998) Melting of Garnet Peridotite and the origin of Komatiite and depleted Lithosphere. J Petrol 39:29-60

Welsch B, Faure F, Famin V et al (2013) Dendritic crystallization: a single process for all the textures of olivine in basalts? J Petrol 54:539-574. doi:10.1093/petrology/egs077

Winpenny B, Maclennan J (2011) A partial record of mixing of mantle melts preserved in Icelandic Phenocrysts. J Petrol 52:17911812. doi:10.1093/petrology/egr031

Wood BJ, Blundy JD (1997) A predictive model for rare earth element partitioning between clinopyroxene and anhydrous silicate melt. Contrib Mineral Petrol 129:166-181. doi:10.1007/ s004100050330

Workman RK, Hart SR (2005) Major and trace element composition of the depleted MORB mantle (DMM). Earth Planet Sci Lett 231:53-72

Wright TL, Doherty PC (1970) A linear programming and least squares computer method for petrologic mixing problems. Geol Soc Am Bull 81:1995-2008. doi:10.1130/0016-7606(1970)81

Yang H-J, Kinzler RJ, Grove TL (1996) Experiments and models of anhydrous, basaltic olivine-plagioclase-augite saturated melts from 0.001 to 10 kbar. Contrib Mineral Petrol 124:1-18 